\title{
A Mysterious Power: Industrial Accidents and the Legal Construction of Employment Relations in Massachusetts, $1800-1850$
}

\section{CHRISTOPHER L. TOMLINS}

to the Hon. Nathan Hale Esq.

President of the Corporation of the Boston \& Worcester Rail Road

Sir,

Mr Gilham Barnes has requested to me to explain to you the nature of the injury sustained by him on the road last June and his situation.

The left arm was so injured that amputation was necessary. The back was seriously injured. The nervous system underwent a concussion, which disturbed his consciousness many days.

Mr Barnes has a wife [and] three or four boys. The eldest is just recovering from typhus fever. He is an industrious poor man, who and whose wife are cheerful laborers and maintain and train their children to become good citizens. If your Corporation ever indulge in a generous sympathy toward humble industry crushed by the mysterious power of your road, Mr Barnes presents a strong example.

With great respect I have the honor to be, Dear Sir, yours \& c.

Geo. C. Shattuck

Boston, Sept. 6, 1837'

On 16 June 1837, at a little after six o'clock in the morning, a train

Christopher L. Tomlins is Senior Lecturer in Legal Studies, La Trobe University, Melbourne, Australia.

Law and History Review Fall 1988, Vol. 6, No. 2

(C) 1988 by the Board of Trustees of the University of Illinois 
of cars carrying lumber and gravel and crowded with twenty or more Irish track laborers and other workmen left the Boston depot of the Boston \& Worcester Railroad Corporation bound for Worcester. About four miles out, just after the train had passed the City Mills and was nearing the Brookline road, a wheel on one of the cars broke. The train was thrown from the tracks. Two men were killed and several others severely injured.

Among the injured was a man named Gilham Barnes, engaged by the Corporation about two weeks before to carry out maintenance work on several bridges between Boston and Worcester. On the previous day, Barnes, his brother Luther, and one of the men who worked with them had ridden the same train (an unscheduled track maintenance train known to the corporation as the "gravel" train) as far as the Arsenal bridge, which carried the railroad over the Watertown road in Brighton, to deliver materials and tools. On the morning of the sixteenth, Barnes sent the others by wagon via the Mill Dam toll road to begin work on the Arsenal bridge while he made arrangements with the conductor of the gravel train for additional materials to be carried to the Worcester bridge. Barnes intended, it would seem, to ride the gravel train as far as the Arsenal bridge where he would jump off and join his workmen. "We saw the train going out just after we paid [the] toll," Luther Barnes later recounted. "Then near City Mills we saw shingles \&c all about. I saw my brother running towards us. He waved his hat twice. And he held up his arm and I saw blood and flesh."2

Luther put his brother in the back of the wagon and carried him back to the house in Charles Street he shared with his sister's family. By the time they got there, Gilham was "all distressed." His sister found him "seriously wounded .. . disfigured and bruised and his face full of gravel." Shortly after, his left arm was amputated. He was to remain confined to the house for several months.

Early in September, Barnes approached the Boston \& Worcester Railroad Corporation to seek compensation, using his doctor as an intermediary. The Corporation had already furnished relief to others injured in the accident and to the families of those killed-Oliver Everett, for example, had been allowed "full wages during all the time he was unable to work" by reason of his injury - and the president of the Corporation, Nathan Hale, indicated that the board of directors would entertain a request for assistance if Barnes made a personal plea. Rather than approach the board in the manner of a supplicant, however, Barnes chose to retain an attorney, Abraham Moore, to act on his behalf. Moore wrote to Hale on 16 September requesting that he respond to the letter from Dr. Shattuck. ${ }^{3}$ Barnes "would gladly avoid any unpleasant alter- 
cation," Moore indicated, but "finds himself in a situation which calls on him, in duty to himself and his family, to seek some remuneration for the injuries he has sustained as he thinks by the unwarrantable carelessness of your agents." Moore indicated that unless the matter received the "early attention" of the board of directors, Barnes would be forced to sue. Hale did not respond, and three days later Moore filed a suit in the Suffolk County Court of Common Pleas seeking damages of $\$ 10,000$ in compensation for injuries that had rendered the plaintiff "wholly unable to earn a support for himself and family during his natural life."

The common pleas hearing resulted in a decision for Barnes, forcing the railroad to appeal to the Supreme Judicial Court of Massachusetts. At this point, by mutual agreement, the matter was referred to a panel of referees. After extensive hearings, the Corporation was found to have owed Barnes a duty of care rendering it responsible for injuries caused by the negligence of its agents, and Barnes was awarded $\$ 3,000$ and his costs. $^{5}$

The suit mounted by Gilham Barnes was the first of a flood of suits alleging that employers were legally obliged to compensate employees for injuries arising in the course of their employment that came before American courts in the quarter century prior to the Civil War. ${ }^{6}$ This new phenomenon of employer liability suits marked a decisive moment in American labor and legal history, for it confronted courts with a demand that they impose on employers a clear legal obligation to safeguard their employees' present and future earning capacity commensurate with the employer's claim to the employees' obedience on the job. Gilham Barnes's success suggests that at the outset the possibility of legal intervention in the employment relationship to impose such an obligation was by no means foreclosed. So far as the legal responsibilities of employers in their relations with employees were concerned, that is, it was a moment of openness and uncertainty in American jurisprudence.

Yet the moment was short-lived. Just over a month after Barnes's attorney filed suit, an engineer, Nicholas Farwell, lost an arm in a derailment. Parallels between his suit and that of Gilham Barnes abound. Both sought restitution from the same employer. Both employed the same attorney, Abraham Moore (in fact, Moore delayed filing Farwell's suit until the result of the Barnes case was known and then modelled his declaration on Barnes's experience). ${ }^{7}$ But whereas the common pleas had found for Barnes, in Farwell's case the court found for the railroad. Thus it was the plaintiff who was forced to appeal. Once before the Supreme Judicial Court, the case went to a jury trial (nisi prius) rather 
than to referees. When that jury could not agree whether the defendant was liable or not, the parties agreed to submit the case to the full court for a decision on the defendant's liability as a matter of law. The outcome was a trenchant denial of the plaintiff's right of recovery. Led by its chief justice, Lemuel Shaw, the court delivered itself of an interpretation of employer liability that effectively left the railroad immune from suits brought by its employees. Over the following decade, Farwell v. Boston \& Worcester Railroad became the leading case in the common law of employer liability, treated not only in Massachusetts but throughout the anglo-American jurisprudential world as an authoritative statement of the limits of an employer's responsibilities in any industrial situation.

Perhaps inevitably, historical analysis of early employer liability jurisprudence has tended to focus on its fiscal effects, for Chief Justice Shaw's judgment was clearly a substantial saving for the railroad. Having sought $\$ 10,000$, Nicholas Farwell eventually received about $\$ 700$ in benevolent assistance. Writ large, it would appear that, as Leonard Levy put it thirty years ago, "American capitalism, at a critical stage in its development, was relieved of an enormous financial burden for industrial accidents which it would otherwise have incurred." ${ }^{8}$ Some scholars have gone further, building on this focus to argue that Shaw's embrace of a highly restricted doctrine of employer liability was one element in a more general move toward the purposeful reformulation of private law to subsidize new enterprise and promote the social and economic interests of entrepreneurs, an instrumental response to capitalism's "need" during the early phases of industrialization for a legal environment facilitative of capital accumulation. ${ }^{9}$

Yet such a focus may not be the most appropriate way to approach the issue. First, it may well misrepresent the origins of the impulse for legal change. Recent research on the history of tort law suggests that the conflicts over liability that accompanied industrialism were sparked by pressures to widen the arena of tortious liability, not to restrict it. According to Robert Rabin, injurious behavior in the preindustrial era was governed not by strict liability principles but by an assumption of no-liability outside carefully demarcated areas. ${ }^{10}$ Considered from this perspective, the rejection of employer liability seems to have been more an attempt to preserve the status quo in the face of employees' presentation of literally unprecedented claims for adjudication than an aggressive assault on previously uncontroversial notions of a master's responsibility for the welfare of his servants.

Second, as Robert Gordon has pointed out, the "needs of capitalism" argument assumes a level of causal determinacy between social and legal phenomena that approaches reductionism. Comparative research 
on other societies discloses the absence of any necessary causal connection between industrialization and the appearance of a narrowly drawn doctrine of tortious liability; nor should Shaw's action in embracing such a narrowly drawn doctrine in Farwell's case be taken to have guaranteed American capitalism the particular set of consequences that the "needs" argument predicts, given that the doctrine itself remained open to the infinite variety of interpretation that critical analysis has disclosed at the center of the adjudication process. " Once the indeterminacy of doctrine is recognized, in short, functionalist arguments become highly problematic. "Without for a moment disputing that the forms that industrial capitalism and the negligence principle took in the 19th-century United States might be related," Gordon writes, "is the evolutionary-functionalist hypothesis (law meets the needs of the developing economy) the most plausible means of relating these two things?"'12

Gordon's telling critique of evolutionary-functionalism is this essay's point of departure. Its goal is a "more plausible" explanation than those so far developed by labor or legal historians of the relationship between court decisions limiting employer liability in industrial accident cases and the particular form that industrial capitalism was taking in the United States by the middle decades of the nineteenth century. In Part I, I offer an analysis of the material and ideological circumstances in which debates over industrial accidents and the role of the courts occurred. In Part II, I use Barnes's and Farwell's cases to examine in detail the cut and thrust of legal arguments over whether the assertion of employer liability for employee injuries should be accepted or denied, and why. In Part III, I offer a new interpretation of the courts' approach to employer liability.

\section{Industry and Order}

Were we required to characterise this age of ours by any single epithet, we should be tempted to call it, not an Heroical, Devotional, Philosophical, or Moral Age, but, above all others, the Mechanical Age. It is the Age of Machinery, in every outward and inward sense of that word; the age which, with its whole undivided might, forwards, teaches and practises the great art of adapting means to ends. Nothing is now done directly or by hand; all is by rule and calculated contrivance. ${ }^{13}$

In Thomas Carlyle's remarkable "Signs of the Times," Leo Marx has argued, one may find encapsulated the essence of a vast sea change which swept through the society and culture of the early nineteenth 
century. ${ }^{14}$ Carlyle's essay acknowledged and traversed the new and apparently beneficial technological artefacts which were revolutionizing everyday life. "Our old modes of exertion are all discredited, and thrown aside.... For all earthly and for some unearthly purposes, we have machines and mechanic furtherances." Yet for Carlyle machines were but an aspect of something far more important, something he denominated "mechanism" and which he saw as the true heart of social change. Far transcending mere machinery, mechanism encompassed the era's manifold attempts to achieve a purposeful rearrangement of human energy through the creation of functionally specific institutions and organizations, each dedicated to the reconstruction of its particular segment of material or intellectual life as a taxonomy of procedures. "Men are grown mechanical in head and in heart, as well as in hand.... Not for internal perfection, but for external combinations and arrangements, for institutions, constitutions, - for Mechanism of one sort or other, do they hope and struggle. Their whole efforts, attachments, opinions, turn on mechanism, and are of a mechanical character." 15

Carlyle's essay traced the impact of mechanism "in all the great manifestations of our time" - intellectual, practical, political, artistic, religious, moral. Everywhere, he argued, it threatened a lamentable distortion in the human condition: "excessive emphasis upon means as against ends, a preoccupation with the external arrangement of human affairs as against their inner meaning and consequences." Mechanism signified the displacement of spirituality by selfishness, of the "primary, unmodified forces and energies of man," by "immediate "motives,' as hope of reward, or as fear of punishment." Mechanism enshrined self-interest as the guiding principle of human affairs. "Selfdenial, the parent of all virtue, in any true sense of that word, has perhaps seldom been rarer," while virtue itself had become "but a calculation of the Profitable."

Such a turn of events might well be productive of many palpable benefits, Carlyle acknowledged. "By our skill in Mechanism, it has come to pass, that in the management of external things we excel all other ages." Ultimately, however, "this faith in mechanism, in the all-importance of physical things" was "a threat to the necessary balance in the human situation," one that risked the destruction of "Moral Force."16

Thirty-five hundred miles to the west of Carlyle's Edinburgh, the misgivings that haunted the Scottish essayist seemed remote. In August 1830, for example, at a meeting in Boston's Faneuil Hall called to encourage state promotion of the construction of a railroad to the Hudson River, Benjamin Hallet located moral force not in the exercise of caution in the pursuit of self-interest but rather precisely in the release 
of self-seeking industrial and entrepreneurial energies from inhibiting restraints. To Hallet, the capacity to extend "facilities of intercourse" such as railroads to ever-wider segments of the populace exemplified the "vast moral power," of capital investment. Enterprises such as these confirmed the truth of that great principle that underpinned the philosophy of America's political economy: "Develop the resources of the country - place the means of wealth within the reach of industry, and you produce the happy medium in society." 17

Hallet's unquestioning embrace of the panacea of "development" displays none of Carlyle's spiritual ambivalence about the nature of industrialism. ${ }^{18}$ Yet for all the brash confidence of men like Hallet, Carlyle's critique had a major resonance for Americans. ${ }^{19}$

That resonance had been there from the outset. At its beginning, the new republic's peculiar claim to uniqueness inhered principally in its capacity to offer to all its citizens the promise of both material sufficiency and personal liberty through the successful reconciliation in one republican ideology of values supportive of a capitalist market economy with those embracing a social order of free and independent men. ${ }^{20}$ Almost immediately, concern for the realization of that promise led many of the revolutionary generation to oppose pursuit of any economic trajectory that would take the new nation too close to the European model and the "loathsome dependence, subservience, venality, and corruption" it had bred. ${ }^{21}$ Theirs was not a critique of industrialism per se. $^{22}$ What aroused their apprehension, rather, was the prospect of the appearance in America of "great manufactures... which cannot be carried on, but by rigid system and immense capitals," for these would undermine rather than reinforce the unique social relations of production that might be achieved in a republican political economy. ${ }^{23}$

The approach to industrialism implicit in "the Republican vision of the 1790s" complemented that ideology's other main componentsits politics of hope, its denial of natural inequalities and of the inevitability of hierarchy in human affairs, its promise of a universal prosperity through moderate toil. ${ }^{24}$ This was not, as Joyce Appleby has demonstrated, an attempt to divert America from "capitalism," but rather a demonstration of the variety of alternative paths of development which capitalism could take. In the organization of the economy no less than society as a whole, the goal was the liberation of the "free and independent man" from the controls imposed by authoritarian institutions and privileged elites. ${ }^{25}$

Yet what to the Jeffersonians was an exhilarating attempt to democratize and demystify the exercise of political and economic power in American society was to their political opponents no more than the 
encouragement of anarchy. Particularly in a post-Revolutionary world of rapidly increasing spatial and social mobility, Federalists looked upon "the independence of individuals and the voluntary cooperation of private persons" as no better than a democratic cacophony that threatened society's continuance. ${ }^{26}$ By the 1820 s, their depictions of contemporary life as impossibly chaotic and disorderly had widened to become a pervasive and enduring theme of American life. ${ }^{27}$ Values of discipline, hierarchy, and control were becoming increasingly prominent alternatives in the definition of what constituted a properly republican social order to the Jeffersonian ideal of spontaneous association among free and independent men. ${ }^{28}$

One result, as David Rothman and others have demonstrated, was the multiplication of specialized institutions designed for the inculcation of orderly practices in subordinate populations. "The almshouse, orphanage, penitentiary, reformatory, and insane asylum were all erected and meticulously systematized to deal with the deviant and the dependent." 29 Represented as recreations of the mythical organic, hierarchical, stable communities of pre-Revolutionary times, these were, in fact, wholly disciplinary institutions, dedicated, to use Carlyle's words, to the production of order "by rule and calculated contrivance." They were procedural machines, the means by which "social victims" might be reprocessed and transformed into "respectable citizens." ${ }^{30}$

Each of these institutions has its own history and its own explanatory discourse of professionalization and reform wherein, in large part, its origins and inspiration are to be found. Those discourses, however, shared certain characteristics. Of these, none was more important than their common assumption that human beings could be "managed"; that is, their behavior and motivations altered through the employment of appropriate disciplinary techniques. "By management," the English Whig, James Burgh, had rhapsodized in 1775, "the human species may be moulded into any conceivable shape." ${ }^{31}$ Rothman's description of the penitentiary as "a conscious effort to instill discipline" by means of an institutional routine characterized by a number of established elements - "a set work pattern, a rationalization of movement, a precise organization of time, a general uniformity"-is equally appropriate as a description of any of the great multitude of social settings in which this new theme of management may be detected, for in each of those settings the goal was the same. "A regimen applied to the body by the external force of authority would first become a habit and then gradually be transformed into a moral preference. Through routinization and repetition, the regimens of discipline would be internalized as moral duties." ${ }^{32}$ 
Of all the settings into which the techniques and practices of management were introduced, none was to prove more enthusiastic or enduring in its reception than the industrial enterprise. The overwhelming tendency of historians to locate the genesis of "management" in the industrial revolution and to identify it as preeminently an industrial practice amply attests to this. ${ }^{33}$ In England, it was the first generation of factory masters - men such as Watt, Boulton, Strutt, Wedgewood, and Awkwright - that brought the new ideology to bear on the world of work in the service of establishing the rational and methodical deployment of labor their new large-scale enterprises demanded. ${ }^{34}$ The eventual establishment of a factory system in the early-nineteenth-century United States brought comparable developments, notably in the attempt by the Boston Manufacturing Company to create the factory as a "total institution" that would allow the company exclusive supervisory control over the environment in which work was performed. ${ }^{35}$

Given that, as we have seen, to many in the Revolutionary generation the distinguishing quality of a truly republican industrialism had to be precisely its avoidance of any such "rigid system" of labor discipline and managerial authority, the impulse of America's early industrial proprietors to achieve a disciplined labor force through "management" of their employees was highly controversial. Jeffersonians, according to Anthony Wallace, found the very idea of management immoral, objecting vociferously to the principle of subordination it entailed. Believing that men were accountable not to their superiors but to their peers, Jeffersonians "did not think very seriously about the problems of designing efficient bureaucratic management," trusting instead that human reasonableness would flower once "artificial restraints of property, class, government, and religion were removed, and spontaneous associations could arise." ${ }^{36}$ Yet the mounting uncertainty as to the value of that unsettling spontaneity, that absence of traditional "restraints," we have observed in the post-Revolutionary social order offered American factory masters considerable opportunity to convince their peers of the propriety of their vision of the industrial order. Just as in England, where Jeremy Bentham proclaimed the work of moral reformation to be a "species of manufacture," American factory masters claimed that their establishment served social and not merely economic purposes. ${ }^{37}$ Mills "under right management" would help combat "the natural tendency of accumulating vice, ignorance, and poverty," introducing in their place "habits of order, regularity, and industry" and establishing thereby a "broad and deep foundation" for "public and private future usefulness." As in the asylum so in the mill, "management" was the means through which, it was said, improvement in the moral character of the 
population might be achieved, bringing into existence the "exemplary republican work force" that would be the salvation of a society in the throes of disorder. ${ }^{38}$

Historians have not failed to appreciate the potential for oppression in the disciplined control sought by the factory proprietors. They have, however, generally accepted that the creation of an ordered and regularized work environment was one of the facts of life during the transition to industrial capitalism. ${ }^{39}$ But on closer examination, the proposition seems open to question. Certainly the expanded scale of the organization of labor in New England's new textile enterprises and, later, on the railroads altered the prevailing character of work. In both instances, employers sought to substitute routinized regimes of employment for the "discretionary and spasmodic" mien of the craftagrarian past through the creation of disciplinary and supervisory hierarchies..$^{40}$ Yet just as contemporary research in industrial sociology has indicated that formal descriptions of the structure of workplace relations usually conceal a far more contingent, even chaotic, reality, so we may be justified in suspecting that precisely the same was true of earlynineteenth-century workplaces.

Consider the physical working conditions prevailing in many earlynineteenth-century industrial establishments: in most cases, factory work was physically a miserable experience. Cramped rooms and reverberating machinery were bewildering and oppressive and the work incessant and enervating. Sickness, or "mill fever," was an almost invariable consequence of commencing work in a textile mill.."

Contradictions between the image of managed machine-paced order and a more disorderly reality were also implicit in the work rhythms and habits of the largely rural work force. Drinking and gambling at work, visiting and talking with other operatives, and in particular absenteeism and transiency, all rendered the formal regularity of the mill somewhat superficial. Managers could invoke disciplinary sanctions in individual cases - at least one Hamilton Manufacturing Company employee was discharged because she was caught "dancing in the mill"but their capacity to enforce those sanctions systematically was in fact quite limited. At Lowell, mill owners organized authority hierarchically through delegation to workroom supervisors of immediate supervision and control of employees, but the exercise of discipline could easily clash with the interests of those same overseers in keeping up production in their respective sections. More often than not, an overseer faced with a breach of the mill's "order" would simply turn a blind eye. ${ }^{42}$ In the Slater mills of Dudley and Oxford, considerable disciplinary authority was effectively surrendered by managers to heads of family while that 
retained in management hands was all the time subject to negotiation, rendering its systematic application uncertain. ${ }^{43}$ Outside the mills, even these basic attempts at creating systems of authority were lacking. Most early American entrepreneurs, Richard C. Edwards has noted, tended to rely on their own personal power and authority for control of their establishments. This was hardly conducive to the achievement of an orderly industrial environment for, as Edwards finds, the exercise of that power "was typically erratic and arbitrary" ${ }^{4}$ In assessing the performance of English entrepreneurs, Keith Tribe has similarly argued that the development of techniques for systematic supervision of large bodies of labor did not really begin until after mid-century, and that until then "size meant chaos." 45

There is, therefore, a not inconsiderable irony in the imagery of regularity and orderliness to which early-nineteenth-century industrialists resorted in attempting to describe the reality of their enterprises. Industrial "order" was to an important extent a mask for arbitrariness and confusion, a facade behind which employees daily confronted an unpredictable terrain. ${ }^{46}$

Of all the "manifold uncertainties" with which workers had to contend each day at work, none was more oppressive than their constant vulnerability to violent accidents. ${ }^{47}$ Fleeting glimpses of work injuries available through surviving records underscore how closely violent death attended working people. Take, for example, the case of Charles Goddard, thrown twelve feet head first into a brick wall by machinery in operation at the Marine Railway in Boston; or Jeremiah Menies, whose life ended abruptly on the Fourth of July in 1829 when his ribs were crushed and his back broken by a blow from a hawser at Barnes's Wharf. Then there was David Sullivan, found "hanging by the legs, in fragments," following the bursting of a locomotive steam engine boiler on the Eastern Railroad; and Charles Miller, who died at the Massachusetts General Hospital of injuries received at Merrill and Brother's paper manufactory, "by being accidentally caught by a shaft in said mill while revolving with great rapidity, he being carried round several hundred times, coming in contact with the ceiling above thereby bruising his flesh and breaking many of his bones."48

Examined individually, incidents such as these lend descriptive weight to the proposition that nineteenth-century industrialism was chaotic and disorderly. They give added meaning to Seth Luther's charge that "the whole system of labor in New England ... is a cruel system of exaction on the bodies and minds of the producing classes." ${ }^{\prime 49}$ Examined in aggregate, however, one may detect patterns in their incidence that suggest they signify a lot more besides. 
The absence of any requirement for the recording of industrial accidents in Massachusetts prior to the late nineteenth century makes reliable estimates of their incidence during the earlier part of the century next to impossible. ${ }^{50}$ Employer records of this era are generally silent about injuries on the job, and few of the recent histories of antebellum American manufacturing have had anything substantial to offer on the subject. ${ }^{51}$ What evidence there is, however, suggests that industrial accidents were actually quite rare during most of the first four decades of the century. An inspection of the records of various medium-to-large construction projects of the prerailroad era, for example, discloses few mentions of injury to any participant. During the ten years from 1794 to 1804 that Loammi Baldwin was superintendent of the construction of the Middlesex Canal, he recorded only three instances of injury to anyone involved in the project. $^{52}$ Similarly, at the conclusion of construction of the new Suffolk County Court House in Boston in 1813, the architect in charge, Charles Bulfinch, reported that only one injury had occurred during the project. ${ }^{53} \mathrm{~A}$ similar story is told by the records of Loammi Baldwin, Jr., engineer in charge of the construction of a naval dry dock at Charlestown. Throughout the period of construction only two accidents are mentioned, the first in 1831, when one man was killed and several injured by the collapse of a wooden retaining wall in a major excavation, and the second, some fifteen months later, when Baldwin's deputy, George M. Dexter, reported that a carpenter named Johnson had dropped on his foot a large chisel that he had been sharpening, "cut[ting] off his big toe and half the next, as clean as possible." 54

Work accidents, therefore, appear to have been relatively unusual in the 1820 s and early $1830 \mathrm{~s}^{55}$ They became considerably less so in the $1840 \mathrm{~s}$ and $1850 \mathrm{~s}$. Analysis of the reports of coronial inquests conducted within Suffolk County between 1830 and 1860 indicates that the proportion of deaths resulting from work-related accidents to all deaths by violence rose from roughly one in twenty-six in the 1830 s to one in fifteen in the 1840s and one in seven in the 1850s. ${ }^{56}$ This increase is not, on the face of it, surprising, given that the period from the late 1830 s on witnessed the diffusion of technological innovations - the railroad, the steamboat, the stationary steam engine-which historians have commonly identified with an increase in workplace risk. Few of the fatal industrial accidents reported by Boston's coroners, however, could be attributed to the risks of operating at the frontier of the era's technological capacity. Rather the circumstances of accidents were typically mundane. Austin Fenlee, a seaman on the brig Emir, was killed on 4 December 1828 because a flimsy staging made of oars collapsed as he worked at putting a hoop on the brig's foremast. Samuel Welch, 
at work in the rigging of the schooner Eliza Ann on the morning of 1 September 1829 , fell from the main top because the masthead, "being very rotten," broke off. ${ }^{57}$ Numbers of common laborers died in falls through the unguarded scuttles of warehouses, slipped from icy scaffoldings, or perished when banks of earth collapsed in construction projects. Among railroad workers, brakemen were the most liable to injury simply because railroad bridges were generally constructed with insufficient clearance to allow safe passage of the car and the brakeman on top. ${ }^{58}$

Scholars in the field of industrial sociology and other contemporary commentators have argued that although it is common to see industrial accidents attributed to the "inevitable" risks of operating at the cutting edge of technological capacity, they are, in fact, far more often caused by the pressures brought to bear on employees by their employers' desires to minimize costs and maximize productivity. An employer determined to keep work moving and costs low will quite routinely place his employees in physical danger in their day-to-day employment. "The more rationalized the work, the faster the machines run, the less time wasted between operations ... the greater the chance that in the short or medium term the work force will be palpably injured by its labor." 59 Evidence at a level of detail that would permit rigorous testing of this hypothesis as an explanation of the occurrence of work injuries in the first part of the nineteenth century is hard to come by. Such illustrations of workplace pressures as are available, however, tend to support the proposition that the causes of accidents are to be found in the sociology of production rather than in the pressure of "economic growth" against the outer limits of technical achievement and human knowledge.

Take, for example, a series of letters describing the use of a diving bell in the construction of the Charlestown navy yard dry dock during the winter of 1833 written by George Dexter, clerk to the superintendent of the yard, to Loammi Baldwin, Jr., the chief engineer. On the first morning of work involving use of the bell, Dexter told Baldwin, the men "all held back and seemed unwilling to go." Some demanded double wages before they would go in the bell, others simply declined "from fear." Dexter described to Baldwin how he had "sent out of the yard for an Irishman who had been working the last summer on the bank at the bottom of the yard, and put him 'nolens volens' into the bell and descended with him." The experience was "not very unpleasant, excepting the pressure of air on the ears," and the demonstration apparently sufficed in allaying the men's anxieties and persuading them to work in the bell at their regular wages. Dexter indicated, however, 
that operation of the bell was going to be problematic. The air hose was faulty and "the scow on which it is placed is an old affair and leaks badly."

Dexter's next letter shows that by the time operations began in earnest the following week, the men were apparently having second thoughts about the bell. "The men were awkward and did not work to much advantage." Dexter arranged for a subcontractor to take over the underwater excavation and proudly told Baldwin of the 40 percent saving in costs this had effected. His letter, however, revealed that the price the subcontractor had agreed to had placed his workers under enormous pressure to avoid delays. "Our men would not work in the bell when the thermometer was below 32. Mitchell and his men are at work today and the thermo. at 10." Dexter reassured Baldwin that "we are daily gaining information and experience about the use of the bell," yet his letter was a catalog of near-disasters. "The air pump is good for its size, but is not large enough, and the divers often have to ring for more air. When the bell is full of air, by constant pumping, it will keep a supply, but when the men are at work and cant the bell a little the air escapes and the pump cannot replace it quick enough." Even raising and lowering the bell was a major problem. "The rope by which the bell is suspended is $5 \mathrm{in}$. white rope, roved through 2 three fold blocks $14 \mathrm{in}$. sheave. This rope, however, by being in the water has become an 8 in. and sticks badly in the mortices of the blocks." Moreover, "the barrel on which the rope is wound up does not answer well. The slope is too gradual which causes the rope to surge badly." Dexter indicated that he had contemplated substituting a chain for the rope, but had not done so as this would prevent the use of the bell in cold weather. ${ }^{60}$

Notwithstanding the difficulties described in Dexter's letters, there is no evidence that the operation of the navy yard bell was not accidentfree. Certainly no report of any mishap appears in the chief engineer's papers. The example, nevertheless, is instructive, in that it reveals how considerations of cost and speed could impinge upon considerations of safety to the detriment of the latter. A leaking scow, an inadequate air pump, a rope that swelled in water and stuck in its blocks, a badly designed windlass - none of these were problems at the leading edge of early-nineteenth-century technology. Yet Dexter never so much as hinted that he was considering suspension of the bell's use until the faults were corrected. Neither the weather nor shoddy equipment nor the anxiety of the workmen involved was to interfere with the schedule of construction operations.

Similar hints of the negative impact of considerations of cost and speed of operation upon the safety of the working environment appear 
amongst the reports of the Suffolk County coroners. When Isaac Tirrell's steam engine boiler blew up on Christmas Eve in 1845, killing his son William and fellow worker William Ford, Tirrell told the inquest that the accident had been caused by Ford's incompetence in regulating the quantity of water in the boiler. According to the testimony of master machinist Stillman Chubbuck, however, just the previous week Tirrell had called him in to examine and repair the boiler only to be told that the boiler "was very old, hardly worth repairing, and if he was not careful it would burst and kill somebody." Tirrell, said Chubbuck, had reluctantly agreed to have the boiler patched but had told Chubbuck's workmen to "be as quick as you can about it, for we are in a great hurry." Other workmen in Tirrell's shop claimed that the boiler had been leaking badly and that Tirrell had acknowledged the need to do something about it "when over with his hurry." They described how Tirrell's careless management had "often led us to fear and to remark that we should either be blown up or burnt up." ${ }^{.11}$

During the 1830 s and 1840 s, the pivotal importance of the cost-safety nexus took on a peculiar clarity in Massachusetts. Employers found themselves participating in an increasingly competitive local economy and reacted by intensifying the pace of work. By the late 1830s, indeed, the performance of work in Massachusetts had become entangled in what W. G. Carson has trenchantly described as a "political economy of speed." ${ }^{2}$ With entrepreneurs scrabbling for advantage in an increasingly rapacious competition for new markets and scarce investment capital, rapidity of development and operational intensity became the essence of industrialism in the state.

What was particularly noteworthy about the political economy of speed was the dramatic intensification of workplace pressures that it brought, with predictable results for the safety of the environments in which people worked. In the New England textile industry, for example, the rapid expansion of mill capacity that occurred during the 1830 s greatly increased competition in the industry, precipitating a fall in revenues and profits. Slackening consumer demand after 1837 rendered the situation acute. Mill agents under pressure to increase productivity and reduce unit costs turned to the intensification of work through the techniques of speedup and stretch-out and the introduction of premium payments to the most productive overseers. At Lowell, the "leisurely atmosphere of the early mills" was transformed over the succeeding decade as work loads effectively doubled while working conditions deteriorated. As one overseer put it: "The necessity which [the supervisor] is under of producing work, of the quality, and in the quantity his employers desire of him, compels him (even when he has a disposition 
to do otherwise) frequently to be apparently harsh and unmindful of those employed under him." ${ }^{63}$ A similar story was unfolding in the smaller southwestern Massachusetts mills where the traditional "family" system of labor organization slowly disintegrated under the pressure of speedup and stretch-out. ${ }^{64}$

The same stresses can be discerned compromising the safety of operations on the region's early railroads. Here, however, the story is more complex. First, the railroads had to compete with preexisting modes and routes of carriage. Owing their origin in large part to the desire of Boston's merchant capitalists to win themselves a share of the booming trade with the west, New England's railroads were intended to counteract New York merchants' water-born dominance over what was seen as Boston's commercial hinterland. Maintaining their edge in competition with road and water transport was clearly always going to be an important constraint upon the railroads' freedom of operation. Operational success, however, itself presupposed success in attracting sufficient investment capital to make the railroad a going concern, while success in this competition to attract and retain capital was in turn dependent upon holding out a realistic prospect of a decent return on investment. In 1828 , for example, the proponents of the projected railroad linking Boston to Albany estimated that a minimum return of 6 percent per annum was necessary to attract the capital required. Significantly, they were able to demonstrate their project's capacity to achieve this return only by deliberately underestimating its recurrent costs. Annual maintenance costs, for example, were set at a quite unrealistic 0.25 percent of invested capital. ${ }^{65}$ The Boston \& Worcester Railroad, chartered in 1831 to undertake the development of the first stage of the route to Albany, followed a similar strategy, deliberately minimizing costs and foreshadowing healthy returns in order to compete for investment. ${ }^{66}$ Indeed, so intense was the desire of the directors "to prove, once and for all, that railroads were a profitable investment" that it led them consistently to underestimate operating (particularly maintenance) costs in order to justify devoting operating revenues to the payment of dividends. $^{67}$

A clear threat to operational safety arose from these circumstances. Having staked the survival of its enterprise upon the promise of substantial dividends, the Boston \& Worcester's board of directors was committed to maximizing speed and minimizing costs in both construction and operation of the road. Given the intensity of competition for capital and the ceiling on freight and passage charges imposed by the existence of alternatives, fulfillment of its pledges was not possible any other way. 
The railroad that resulted was, not surprisingly, "a superintendent's nightmare"-a single-track line operating without signals on which "collision lurked around every corner." ${ }^{\prime 8}$ Collisions at unmarked crossings between road and rail traffic began to occur almost immediately. These were soon joined by a quickening flood of derailments and collisions between trains, bringing injury and death to passengers and employees alike. ${ }^{69} \mathrm{~A}$ rigid scheduling system was adopted as the main, indeed only possible (given the physical plant available), guarantee of operational safety. Yet this was inevitably compromised by constant pressures from the board to increase the intensity of operations. Early in 1839 , for example, the board can be found expressing its "great concern" at the "various accidents, disasters, and occurrences which have recently happened on the Rail Road," especially "the several instances of the merchandize trains running with a much greater speed than are allowed by the regulations heretofore adopted." Less than three months later, however, we find the same board instructing the superintendent "to rescind the regulation by which the enginemen are required to run the passenger trains over the road in three hours, and to direct them to run carefully over every part of the road, especially over all uneven places, and to perform the whole distance in not less than two hours and three quarters." Apart from the board's implicit acknowledgement that the roadbed was not in the best of conditions, its instruction rather contradicted its earlier profession of concern at the speed of the merchandise trains, for it is clear that on a single-track railroad an instruction to increase the speed of one class of traffic was de facto an instruction to increase the speed of all. ${ }^{70}$.

The board's need to increase the intensity of operations, and the resulting increase in the incidence of accidents, had their origins in its initial strategy of minimizing the capital costs of the road. This was underscored in a report of an independent committee set up by the railroad's stockholders at their annual meeting in June 1840 to investigate "why the dividends of this company have not yet exceeded six per cent," a rate, according to the committee "altogether too low, when compared with the reasonable expectations of the stockholders and the eligible position of the road." The committee's report focused on the deficiencies of the corporation's locomotive department. The road's engines, it said, were "of antiquated patterns, deficient in power and decrepit for want of repairs and requiring a constant outlay to keep them in motion." Too small and weak for the roles they had to play, the mechanical strain under which the engines had been placed resulted in constant breakdowns and accidents, considerable expenditure in repairs, and the loss of revenue through delays and lost business. Given, 
moreover, that even when operating smoothly their small size meant they were incapable of hauling large loads, persistent use of small locomotives necessitated that the volume of traffic on the road be increased to an extremely high level. Not only did this mean additional operational expenses in the form of track maintenance and fuel and labor costs, it also materially increased the risk of catastrophic accidents. The committee called for the introduction of heavier locomotives, which "will perform the work of three [existing locomotives], will save the expense of two firemen and enginemen, will obviate the necessity of frequent trains of freight which on Roads with a single track materially retard the transportation of passengers and occasion a waste of fuel and labor and frequent accidents," and "will cause less damage to the Road." It also called for the immediate commencement of work on a second track. "The perils of the way are increasing and must continue to increase with the accession of business ... the security of the travelling public imperatively demands a second track, [for] without such a safeguard it will be impossible for this road to perform its own business and the business derived from the other great roads that unite with it and avoid the recurrence of similar disasters." 11

The deterioration of working conditions in the state's textile mills in the second half of the 1830s and the travelling exhibition of injury and dismemberment on the railroads point up the decisive impact of the political economy of speed on the safety of work in early industrial Massachusetts. Equally important, however, these developments brought to the surface the completeness of the contradiction between employers' idealized image of industry as ordered regularity and the actuality of their employees' day-to-day lives. The result was a burgeoning crisis of industrial control. ${ }^{72}$

Reactions were forthcoming from both employers and workers. For their part, employers placed redoubled emphasis upon the transformative powers of "management." Unsavory or dangerous working conditions were to be addressed through the bureaucratization of managerial authority and the establishment and enforcement of more elaborate codes of rules and workplace procedures. ${ }^{73}$ Once promulgated, these rules and procedures took on a life of their own as a necessary and sufficient condition of the existence of a safe and orderly workplace. Accidents were to be explained not by the pressures visited on the work force as a consequence of their employer's participation in a competitive market economy but by an employee's violation of the rules. ${ }^{74}$ But in fact, as we have already seen, when rules got in the way of production and profit, employers and supervisors could often be found surreptitiously conniving in their breach. ${ }^{75}$ In other words, whether work rules 
accurately described the realities of production, and thus provided a means for its regulation, was in fact highly debatable. ${ }^{76}$ Just how debatable has been demonstrated in the work of historians such as Walter Licht, whose research well attests to the "diffuseness" and "indeterminacy" of early industrial work. "An effort at labor control," Licht writes, "rules often are presented as descriptions of the normal working day. The true picture - of what actually occurred on the job on a daily basis - was more complicated." Whatever those rules tell us about managers' desires to proclaim at least the appearance of rationality, the reality on the railroads was that "work for all grades of [employees] was characterized by contingency and an absence of specification." 77

During the 1830s and early 1840s, Massachusetts workers also addressed the contradiction between the appearance and the reality of industrial work. At first they and those who spoke for them simply offered a counterimage of industrial order to that embraced by their employers. Strikes, speeches, and demonstrations became occasions to air grievances about the depravatory and tyrannical factory system and to invoke a contrasting egalitarian ideal that recalled the communal industrialism of the Jeffersonians. ${ }^{78}$ By the early 1840 s, however, this utopian critique of wage labor and class division had begun to metamorphose into something more deliberate. "Unable to halt what they perceived as the degradation of work," writes Thomas Dublin, "operatives sought at least to mitigate its ill effects," mounting a series of campaigns for the legal regulation of conditions and hours of work in textile mills. ${ }^{79}$ Historians have argued that this altered strategy, with its acceptance by workers of "time and work discipline" as appropriate categories within which to pursue their contest with their employers, meant that the whole contest had moved decisively onto the employers' terrain. As we have seen, however, although the image of that terrain was one of regularity, its reality was one of oppressive arbitrariness and unpredictability. By campaigning to achieve the regulation of working conditions through public intervention, workers were not simply attempting to press on their employers variations to the content of those mutually agreeable categories of time and work discipline. Rather, they were seeking to remold the terrain itself, to legislate in their own terms a modicum of the "order" absent from the reality of "management."

This, then, was the material and ideological context in which the question of employer liability arose in the late 1830s and 1840s. During these years, deteriorating conditions in the state's industrial establishments and the rising incidence of industrial accidents provoked an attempt by employees to expose the hidden abode of production to the gaze and the intervention of public authority and, in particular, to 
employ legal institutions as a means both of protecting themselves from the disorder of a competitive economy and of challenging the ideology of management. The result was a confrontation with employers determined to avoid regulation potentially restrictive of their capacity to pursue production and profits.

The common law of employer liability was one of the key sites on which this confrontation took place. In these cases, plaintiffs resorted to the courts in an attempt to establish the responsibility of their employers for injuries to their employees in the course of their work. By attempting to clarify the nature of the "managerial" power claimed by employers of labor and to hold them accountable for the chaotic consequences of its exercise, however, the plaintiffs were also implicitly demanding that the courts define the limits of their employers' authority over the organization of production. Thus the issue also became a test of the social acceptability and legitimacy of managerial power.

\section{Order and Law}

[W] hile civil liberty is more and more secured to us, our moral liberty is all but lost. Practically considered, our creed is Fatalism; and, free in hand and foot, we are shackled in heart and soul with far straiter than feudal chains. Truly may we say with the Philosopher, "the deep meaning of the Laws of Mechanism lies heavy on us"; and in the closet, in the marketplace, in the temple, by the social hearth, encumbers the whole movements of our mind, and over our noblest faculties is spreading a nightmare sleep..$^{80}$

Gilham Barnes's suit against the Boston \& Worcester Railroad was not resolved until almost two years after his accident. After the preliminary hearing in September 1837 before the Court of Common Pleas resulted in a decision in Barnes's favor, the parties retained additional counsel for an appearance before the Supreme Judicial Court in November. The well-respected Charles Greely Loring took over the principal role in representing the railroad from George Morey, while Abraham Moore sought the assistance of one of the Massachusetts bar's rising luminaries, Rufus Choate, on Barnes's behalf. At a subsequent appearance before the court in March 1838, the parties reported their agreement to resolve the matter before a panel of referees. Hearings began on 27 February 1839 before Emory Washburn, Edward Brooks, and Prince Hawes. ${ }^{81}$

As was his habit, Loring kept extensive records of the arguments and testimony offered by both sides. ${ }^{82}$ From these it is possible to reconstruct 
the hearings more or less word for word. What is revealed is a contest between conflicting doctrinal approaches to the occurrence of an occupational injury. The plaintiff asserted that the railroad owed a duty of care to all whom it conveyed. The corporation contended that the extent of its liability to compensate the plaintiff was determined exclusively by the terms of its contract with its employee.

Abraham Moore opened for the plaintiff. Barnes had come to Boston a poor and penniless man. Through hard work- "we shall prove that he had the reputation of doing more work in a day than any other man in his way in Boston" - he had acquired a small property, which he had nearly freed from mortgage when the accident happened. He was "a moral man of sterling worth," the father of four boys, and the principal means of support for aged and infirm parents. Denying any intention to cast aspersions on the character of the corporation or the "numerous excellent gentlemen who comprise it," Moore nevertheless suggested that the burden of any damages ultimately awarded would be "but slightly felt."

Having thus painted the case as one between a poor but virtuous man and a powerful corporation, Moore introduced the plaintiff's case. Barnes had been retained by the assistant superintendent of the road, William Jackson, to tar and gravel several bridges belonging to the corporation. He had been promised transportation to and from the various locations. On 16 June he had resorted to the corporation's track maintenance train, which had subsequently been derailed when a wheel broke on one of the cars. The plaintiff's case rested on the corporation's violation of its obligation to provide Barnes with a safe means of transportation. Moore called witnesses to testify that the defendant had promised to provide Barnes with transport; that Barnes had been directed to take this particular train on the day in question; that many of the wheels on the cars making up this train were cracked-and indeed that it was the corporation's policy to recycle wheels deemed unsafe for use on its passenger cars by putting them on the gravel cars; and that as a result the train had been derailed.

In his opening remarks for the corporation, Loring attempted to alter Moore's characterization of the dispute so as to recast the roles of victim and oppressor. The corporation, he indicated, commiserated with Barnes. "The defendants and counsel do deeply sympathize with [him]." But instead of availing himself of the defendant's compassion and appealing to its benevolence and generosity as he might have done, Barnes had chosen to stand upon "his merely legal rights." Having taken that route his case had to be judged according to strictly legal considerations. "Feelings of sympathy and commiseration are among the most operative 
and powerful of any of humanity, wisely so ordained that our hands may be ever ready to succour and relieve." Fairness to the defendants demanded, however, that the referees banish such feelings from their minds. "If suffered to mingle in and influence [your] enquiry, their agency becomes a direct injustice and oppression upon the defendants and a greater injury is done to them than the plaintiff has suffered for injustice is a greater evil than bodily injury. .. it must not for a moment be forgotten that the appeal which plaintiff has elected to make to you is not one to your sense of what is due from the sympathy or generosity of defendants but what is due from them as [a] matter of strict right according to the rules of law and evidence." ${ }^{83}$

Loring's straightforward denial of the corporation's liability reflected the prevailing status quo in the law of employment relations so far as concerned an employer's responsibilities in the event of illness or accident involving his employee. Prior to the appearance of employee suits for damages in the late 1830s, the question had been litigated on a number of occasions in both England and America, though sparingly and in many cases indirectly. Scattered eighteenth-century English cases had made passing reference to a master's obligation to support hired servants in the event of sickness, ${ }^{84}$ but by the end of that century courts had become increasingly reluctant to acknowledge that masters owed their servants anything. Rather, the cost of curing a sick or injured servant, and also the responsibility to provide support where the servant was left dependent or destitute, was judged to be borne by the parish in which the servant had a settlement or, in the case of casual injuries, the parish in which the accident had occurred. ${ }^{85}$ "I think, in general, a master ought to maintain his servants, and take care of them in sickness," Lord Mansfield stated in Newby v. Wiltshire (1784), "But the question now is, what is the law? There is, in point of law, no action against the master to compel him to repay the parish for the cure of his servant: no authority whatsoever has been cited; and it seems to me that it cannot be. The parish is bound to take care of accidents." 86 In Scarman v. Castell ten years later, Lord Kenyon held in a case heard nisi prius that a master was under a legal obligation to care for and maintain a sick or injured servant "while he was under his master's roof" as long as the illness or injury was not "the consequence of his own misconduct or debauchery," 87 but in Wennell v. Adney (1802), Kenyon's opinion was dismissed in most devastating fashion by a full court of King's Bench. Aside from Scarman v. Castell, stated Chief Justice Lord Alvanley, there was no authority in English law for the assertion that a master was obliged in law to care for his servant. "I have no doubt whatever that parish officers are bound to assist where 
such accidents as these take place; and that the law will so far raise an implied contract against them as to enable any person who affords that immediate assistance which the necessity of the case usually requires, to recover against them the amount of money expended." But there was no question that the law would raise as an implied term of the master's contract with the servant an undertaking to pay the costs of an injury even if incurred in the master's service. ${ }^{88}$

Scattered evidence from Massachusetts indicates a similar legal and social situation. In 1823, for example, Nathan Dane's Abridgement acknowledged Wennell $v$. Adney as decisive in determining the extent of a master's responsibility for sick servants, noting that "the court thought the parish in which the accident happened was liable." 89 That this was already the case in Massachusetts is confirmed, albeit somewhat indirectly, by Kittredge $v$. The Inhabitants of Newbury, heard by the Supreme Judicial Court in $1817 .{ }^{90}$ Following an accident at a Newbury woollen manufactory, Kittredge, a surgeon, had been called in to amputate the leg of Thomas Dennett, the injured employee. Kittredge subsequently applied to the overseers of the poor of Newbury for payment of his fee. Their refusal prompted a suit. Kittredge lost, but the reason was not that Dennett's employer was liable. Rather, the overseers were excused because the operation had been performed without their approval and the bill presented too late for them to recover the cost of casual relief from the overseers of Newburyport, Dennett's town of settlement.

Cases arising out of controversies over the eligibility of indigent former slaves and their descendants for relief from their town of residence reinforce the point, for decisions in these cases invariably turned upon an explicit comparison between the legal obligation of masters to attend to the welfare of their slaves and the absence of any such obligation toward free laborers. Thus in Littleton v. Tuttle (1796), the overseers of the poor of the town of Littleton sued Tuttle for money laid out in relief of his former slave Cato. Tuttle had bought Cato, then six years old, from one Joseph Harwood in 1779 and had retained him in his service until 1794 when Cato had been injured in some unspecified manner. "He being then a cripple, and unable to labor, the defendant delivered him to the overseers of the poor of Littleton and left him with them, refusing to make any provision for him." The overseers claimed Tuttle was liable to make recompense, but the court found that Cato, "being born in this country, was born free" and thus had a lawful settlement in Littleton, relieving his master of the obligation to support him and obliging the overseers to treat him as they would any other free pauper with a settlement in the town. Slaves, the case under- 
lined, were the responsibility of their masters. Free persons, in contrast, were to be supported, if left destitute, by the community. ${ }^{91}$

As in the case of slaves, the relief of sick or injured apprentices was considered to be the personal responsibility of their masters. ${ }^{92}$ Thus in Powers v. Ware $(1824)^{93}$ the Supreme Judicial Court denied the claim that a master might discharge his apprentice on the grounds that, by reason of incurable illness, the apprentice had become unable to perform the services required of him in his indenture. According to the court, the law in the Commonwealth was as stated in the English case of Rex v. Inhabitantes de Hales Owen, that "the master took him for better or worse, and was to provide for him in sickness." If a master should neglect his duty to care for his apprentice, his neglect would normally provide sufficient grounds for a suit to be brought against him, either by the apprentice's parents or, in the case of poor children bound out to apprenticeships by the town, by the town's selectmen. The grounds for the action, however, were provided by the specific statutory provision that "it shall be the right and duty of parents and guardians, and of selectmen, for the time being ... binding minors as aforesaid, to inquiry into their usage, and defend them from the cruelties, neglects, or breach of covenant of their masters or mistresses," rather than any general statutory or common-law provision facilitating recourse by servants against neglectful masters. ${ }^{94}$

As in the case of slaves, then, a duty of maintenance was required of the masters of apprentices as one element in a highly regulated personal relationship. Both apprentices and slaves were explicitly specified as exceptions to the rule that in the event of sickness or accident the sufferer was left to depend upon his own resources or, more likely, on those of the community through the medium of poor relief. ${ }^{95}$ In neither case was the relation of the parties one that could realistically be generalized to other employment relationships, because in neither case was the relation one grounded on the provision of services for hire. ${ }^{96}$

That employers might not be legally obliged to relieve their employees is not, however, necessarily conclusive of what their practice actually was. Benevolence, the French jurist Pothier advised employers, was an important virtue, "becoming indeed to persons well-off and following distinguished professions." 97 As Loring told the referees in Barnes, it was not to be understood "that the defendants feel such indignation or resentment at the bringing of this suit that their sympathies are chilled or their generosity extinguished. Should your award be against the plaintiff (as they believe it must be) the door of friendly application for relief will still be open." 98 
Evidence of practice in Massachusetts as regards employee injuries is almost nonexistent prior to the 1830 s. What little there is suggests a wide variety of attitudes. In 1803, for example, William Niles, "blacksmith, of Charlestown," sued William Ratchford, "blacksmith, of Boston," for payment of wages owed for "certain work and labor" Niles had performed between April 1798 and May 1802 while employed by Ratchford in his shop in Boston. ${ }^{99}$ Throughout that period he had also lived in Ratchford's house. Ratchford contested the amount claimed and produced witnesses to testify that Niles had been lame and unable to work for a significant period of his term of employment. He sought to have the cost to him of boarding Niles while he was unable to work and the costs of medical treatment that he had paid for set off against his debt to Niles. He also sought the reduction of wages owed Niles by an amount equivalent to the period Niles was off work. The jury agreed, placing the entire cost of his lameness on Niles' shoulders.

Other servants fared even less well. Ratchford at least maintained Niles during his illness, even if Niles eventually had to pay for it. That this was by no means the rule is suggested by an article in the Boston Medical and Surgical Journal in July 1829 complaining of the "extremely cruel and dishonorable" manner in which sick or injured domestic servants were often treated by their employers. Physicians, stated the author, were "not unfrequently" embarrassed by masters who forced their servants to pay their own physician's bills. "The payment of wages should cease during medical attendance, but all further loss belongs to the family whose misfortune it is to have any of their domestics taken sick." The article went on to condemn those who would send a sick servant away to "poor, confined and dirty lodgings" or would "have him confined to a hospital." Masters should be more willing to suffer the expense and inconvenience involved for the sake of a closer relationship with their domestics. "A little feeling shown by a master or mistress to a sick servant would generally be well bestowed, and might be equally well repaid by his future faithful services." ${ }^{100}$ Few, it seemed, took any notice. Analysis of the returns of free patients prepared during the late 1830 s by the superintendent of the Massachusetts General Hospital shows that between one quarter and one third of the number were female domestic servants. ${ }^{101}$

In contrast, the ideology of benevolence seems to have played a rather more prominent role in the employment practices of Massachusetts's corporate enterprises. ${ }^{102}$ This should not be unduly surprising for historians have generally agreed that a paternalistic sense of social responsibility or "stewardship" was a key component of early corporate ideology. Some years ago, Caroline Ware argued that Francis Lowell 
established the Boston Manufacturing Company not only to facilitate the concentration of capital and the organization of textile production, but also "to provide a scheme for protecting his working population." Anthony Wallace similarly finds the mill owners and "managerial people" of Rockdale imbued with a strong sense of responsibility for the welfare of their employees. ${ }^{103}$

By the end of the 1830 s, however, corporate social responsibility was fast becoming another casualty of the political economy of speed as the decade's growing emphasis upon profit and productivity began to strip the business corporation of all but an economic identity. For all their protestations of responsibility in their actions toward their employees, the priority Massachusetts's industrialists increasingly accorded economic factors in determining their policies left them possessed of a cramped notion of what stewardship meant. ${ }^{104}$ In proclaiming that "the door of friendly application" was open to the increasing flood of accident victims generated during the late 1830 s and 1840 s, for example, those owners and managers restated the responsibilities of "stewardship" in the banal terms of the cash nexus, simultaneously teaching their employees that they counted only as the embodiment of their labor. In such circumstances it is hardly surprising that employees so taught should eventually seek counsel's aid to realize a truer approximation of their lost property's worth than corporate handouts which, by the end of the 1840 s, had in any case dwindled to the merest pittance. ${ }^{105}$

In this context, each party to Barnes was addressing the question whether the law should now be made available to facilitate the imposition of social duties on employers in the name of the common good. Moore and Choate stressed the devastation visited on the plaintiff by his injury and insisted that the corporation's legal liability be made coextensive with the moral responsibility which its privileges had brought. Loring, in contrast, attempted to strip the case of ethical content and pare it down to bare contractual essentials.

In thus canvassing in microcosm the relation of law and economy, the two sides employed different legal strategies. For the plaintiff, Choate stressed that liability derived from an extensive legal duty of care owed by the corporation to all who rode its cars, employees and passengers alike. Once the corporation had agreed to employ Barnes and to furnish him with transportation to and from his work, it had brought him within the sphere of those to whom it was obliged to offer indemnity in the event of loss resulting from its neglect of that duty. ${ }^{106}$ For his part Loring retorted that no basis existed in law for the imputation of any such duty of care and argued that the question whether anything was owed in this particular case could only be resolved through an 
examination of the plaintiff's contract. This showed that the defendant had not explicitly promised transportation, but had merely undertaken to supply conveyance for men and materials at its discretion.

The distinction was important, for Loring sought to imply into Barnes's contract a "general rule" promulgated by the corporation that no one in its employ was allowed to use the gravel train other than the gang of laborers specifically assigned to it. It was, said Loring, the defendant's custom to allow its employees the privilege of riding free, but they were directed to use the first car of the passenger train which, as a result, had become widely known as "the labourers' car" or "the Irish car." Barnes was presumed to have been aware of this rule, having worked for the defendant on previous occasions. Thus, if Barnes had chosen to ride on the gravel train he had done so at his own risk. ${ }^{107}$

Loring presented the corporation's rule as an objective fact of life, a managerial pronouncement which was determinative of the reality of railroad work. As he put it in his closing argument, the testimony of the defendant's witnesses had clearly shown "that no men at work on the road except the gang attached to the gravel train were ever directed or authorized to ride upon it" and that on the contrary "such act was contrary to the [corporation's] express rules and orders, well known and understood." Yet testimony given by witnesses for Barnes during the hearing had shown that Loring's "rule" was less than prescriptive in practice. Other employees testified that they too had ridden on the gravel train, usually when accompanying materials being dispatched to points along the right-of-way for use in track maintenance operations. Loring attempted to diminish the significance of their evidence- "No one witness proves it to be customary for any to ride but the gang. A few instances only can be found in which others have been permitted to go [on the gravel train]," and these "were in no case instructed to go there and knew that this was not the regular place, but that another was provided"- - but his protestations were rather beside the point, given that the plaintiff did not seek to prove that he had contracted specifically to use the gravel train but rather hoped to convince the referees that the corporation had a duty to compensate him for its negligence because he had been on the gravel cars with its consent or, as Choate put it, "under such circumstances that a man of sense would suppose himself to have such consent."'108

Loring's argument that the corporation's rule was decisive of its obligations toward its employee was obviously severely restrictive in its implications for the responsibilities that could be imputed to employers. The same argument - that management was a purely private matterwas raised in the final segment of his presentation where Loring turned 
from his narrow focus on the contract between Barnes and the corporation to an examination of the plaintiff's contention that the defendant owed him a duty of care.

Loring's particular target was the plaintiff's contention that the defendants "by their agents and servants negligently and carelessly used in and upon the cars, in and upon which plaintiff was riding two broken cracked and insufficient wheels." 109 That the defendants had indeed equipped the train with wheels which they knew to be cracked - "say 3 or 4" - was conceded. Loring insisted, however, that the mere use of such wheels proved nothing. Rather, two separate issues were involved: first, "whether the use of cracked wheels is ipso facto negligence and carelessness"; and second, if not, "whether there was any neglect or carelessness in this [particular] instance," for example, by using wheels which were particularly badly cracked or by failing to exercise sufficient precaution or examination.

Here arose the legal question of whether any degree of care and prudence was actually required of the defendants in their use of the train sufficient to sustain the plaintiff's contention that they owed him a duty of care. Loring's answer was - virtually none. The train was "not a public train which every one has a right to use on tendering payment for fare or freight" at all. ${ }^{110}$ Rather, it was "the private vehicle of the defendants to be used for their own purposes." Loring's conclusion? "The public has therefore no right or interest in the gravel train; no right to use it on any terms [and] no interest in having it kept safe or strong, any more than it has in having the private waggon or carriage of any individual kept safe or strong." 11 Barnes's case, that is, fell outside the narrow circumstances in which the law would recognize an overriding public interest in regulating the management of a concern and impose a penalty in cases of default in the shape of a presumption of liability. Consequently "no greater degree of care or prudence or skill can be required of defendants than is required of persons of common prudence in the management of their own concerns." 112

Having thus defined the parameters of the defendant's obligations, the question became whether the defendant's actions had breached those parameters or not. "The first question then is, is the use of cracked wheels on gravel trains consistent with ordinary care and prudence?"113 This, Loring argued, could only be determined by reference, first, to the conduct of other railroad corporations; and second, to the actual experience of this corporation. "Now the evidence proves that all other corporations did use these wheels on some or all of their trains. If these gravel trains were generally used with cracked wheels, how can the defendants be said to have been deficient in ordinary care and pru- 
dence?" Outside the exceptional situations of common carriers and carriers of passengers, circumstances already demonstrated to be inapplicable to this case, public prescription of a formal standard of care was not appropriate for there was no "public interest." The only possible test was contemporary managerial practice. Hence, as in the matter of the "rules" supposedly implied into the plaintiff's contract, the managerial position was conclusive of the issue. It was, Loring argued, altogether "monstrous to say that a system used from one end of the continent to the other [and] on every road-is not consistent with ordinary care and discretion."

Loring's forensic efforts notwithstanding, Barnes prevailed and was awarded $\$ 3,000$ in damages. The costs of the hearing - $\$ 436$ (including $\$ 300$ in referees' fees) - were also paid by the railroad. No record of the referees' judgement was kept, so it is impossible to ascertain the precise basis for their decision. Loring himself, however, noted cryptically during Choate's closing argument that the referees seemed to be attaching particular importance to that part of the plaintiff's case that alleged the corporation's use of cracked wheels was a demonstration of negligence sufficient to render it liable. Certainly Loring himself devoted the preponderance of his argument to persuading the referees that liability was a creature of the parties' contract and that the question of negligence should not therefore be admitted. And when Loring finally did address the negligence argument directly, it was in order to demonstrate that it could not apply in the circumstances of this case.

Barnes's case reveals the potential within the realm of legal discourse at the end of the 1830s for the development of an approach to industrial injuries predicated upon the assertion of a public interest in the safety of industrial workplaces. As our examination of the course of argument in the case has indicated, such an approach would have had quite profound implications for the claims of the owners and managers of industrial enterprises that their establishments and practices were private affairs not subject to public oversight. ${ }^{114}$ Barnes is almost the only available example of precisely how those claims might have been invaded, but it is not entirely isolated. In Randolph v. Hill heard in 1836, for example, the Virginia Court of Appeals upheld a jury verdict awarding damages to Hill for the death of his slave by asphyxiation in a mining accident, a verdict based inter alia on the jury's inference from facts presented to it that the defendant's overseer had not exhibited the necessary degree of care and that the defendant's establishment was dangerously deficient in providing only one bucket to draw up laborers from a seventy-foot deep shaft. ${ }^{115}$ As in Barnes the defense argued that such matters were irrelevant unless measured against a standard of 
practice, that the appropriate standard was that prevailing in mines in the district, that the jury had clearly ignored evidence tending to show that the defendant's overseer was no more neglectful of his duties than other overseers in his position, and that the mine was no more dangerous than other coal mines in that locality. By upholding the verdict, however, the court of appeals clearly left it open to plaintiffs to invite courts and juries (or referees) to apply their own standards in determining the substantive question of what constituted a safe working environment rather than leave that matter to the generality of industrialists in a given area. ${ }^{116}$

Barnes v. Boston \& Worcester Railroad was not, however, a case of record and as such was accorded no role in doctrinal debates over the extent of an employer's liability for industrial injuries. Indeed, the principal cases of record in which and from which employer liability doctrine was wrought during the following decade all rejected the widened sphere for tort liability that had been at the heart of the plaintiff's case in Barnes. Either indirectly, by interposing doctrines of mitigating circumstance, or directly, by straightforwardly asserting that the extent and limits of an employer's liability was a purely contractual issue, Massachusetts courts rendered employers substantially immune from injury claims.

Central to this new trajectory was the suit brought by Nicholas Farwell against the Boston \& Worcester Railroad in 1839.

As we already know, Farwell sued the railroad for $\$ 10,000$ in damages to compensate him for the loss of his arm in a derailment caused by another employee's error. Farwell's attorney - Abraham Moore againfiled the suit almost as soon as his success in Barnes's case was confirmed, but at the October 1839 term of the Suffolk County Court of Common Pleas he got a taste of what was to come when the court decided in favor of the railroad. The plaintiff appealed the common pleas judgment to the Supreme Judicial Court, sitting nisi prius. At that hearing, however, the jury could not agree whether the defendant was liable. ${ }^{117}$

At this point the parties agreed to refer the case to a full bench of the court for it to determine whether, in the wake of the recent decisions in the English case Priestley v. Fowler (1837) ${ }^{118}$ and the American case Murray v. South Carolina Rail Road Company (1841), ${ }^{119}$ the defendants could as a matter of law be held liable to one employee for an injury alleged to have resulted from the negligence of another. Ironically, the attorney retained by Abraham Moore for Farwell's Supreme Judicial Court appearance was none other than the same Charles Greely Loring who had represented the railroad in Barnes. ${ }^{120}$ Loring's performance in Farwell's case is worth examining closely for at least one analysis of the 
outcome in that case has attributed the result in part to Loring's poor performance on the plaintiff's behalf. "Rarely in the history of American law," Morton Horwitz wrote in 1976, "has so significant a case of 'new impression'. . . been so thoroughly determined by the intellectual impoverishment of counsel."121

Priestley v. Fowler and Murray v. Rail Road were both suits brought by injured employees against their employers. Priestley was a butcher's boy whose leg was broken when an overloaded cart driven by another of the butcher's employees overturned while he was riding on it. Murray was a fireman injured in a derailment. As in Barnes the actions were both "on the case," the plaintiffs seeking to found their claims on an assertion of a duty of care owed them by the employer and extending to protect them from the negligence of other employees, rather than in contract. Also as in Barnes's case, the defendants' response was in each case first, that no such action was available because no duty was owed beyond those provided for, expressly or implicitly, in the parties' contracts; and second, that even had the plaintiff sued in contract he would have failed because close examination disclosed no evidence that the parties' contracts in fact extended to a promise on the part of the employer to indemnify his employee against the consequences of injury whilst in his service.

The referees in the earlier case, as we have seen, had found for Barnes. In each of these cases of record, however, the court found for the defendants. The English court, for example, rejected out of hand the possibility that a general obligation to indemnify servants against unanticipated injury occurring in the course of employment could be inferred to exist. If such a liability were found, Lord Abinger stated, "the principle of that liability will carry us to an alarming extent." The narrowly drawn and carefully demarcated boundaries of tort liability would collapse in a welter of suits. "If the owner of the carriage is therefore responsible for the sufficiency of his carriage to his servant, he is responsible for the negligence of his coach-maker, or his harnessmaker, or his coachman. The footman, therefore, who rides behind the carriage, may have an action against his master for a defect in the carriage owing to the negligence of the coach-maker, or for a defect in the harness arising from the negligence of the harness-maker, or for drunkenness, neglect, or want of skill in the coachman." Matters would not end there. "The master, for example, would be liable to the servant for the negligence of the chambermaid, for putting him into a damp bed; for that of the upholsterer, for sending in a crazy bedstead whereby he was made to fall down while asleep and injure himself; for the negligence of the cook, in not properly cleaning the copper vessels used 
in the kitchen; of the butcher in supplying the family with meat of a quality injurious to the health; of the builder, for a defect in the foundation of the house, whereby it fell, and injured both the master and the servant by the ruins." Merely to contemplate "the inconvenience, not to say the absurdity of these consequences" was sufficient answer to the plaintiff's plea on the case. As to a plea in contract, although none had been made, a master was "no doubt" obliged to secure his servant's safety while in the course of his employment to the best of his "judgement, information, and belief," but "the mere relation of the master and the servant never can imply an obligation on the part of the master to take more care of the servant than he may reasonably be expected to do of himself." 122

Similar fears were expressed by the South Carolina court in Murray. If the plaintiff were entitled to recover in this suit, said Justice Evans on behalf of the majority of the court, "a new class of liabilities would arise, which I do not think has ever heretofore been supposed to exist," rendering employers vulnerable to an avalanche of suits. Evans canvassed the circumstances in which a court would have found the railroad rendered liable by the act of an agent; the law, he acknowledged, would annex a responsibility in the case of an injury to a passenger or other stranger, or for the loss or damage of goods. But this was for a specific reason: "unless [the principal] be liable, the great operations of life can not be carried on - no man would have adequate security for his person or his property." 123

Because the plaintiff's case did not fit within these established boundaries of tort liability, he was unable to recover unless he could show that the railroad had assumed the responsibility by contract. This he could not do. "With the plaintiff, the defendants contracted to pay hire for his services. Is it incident to this contract that the company should guarantee him against the negligence of his co-servants? It is admitted he takes upon himself the ordinary risks of his vocation; why not the extraordinary ones? Neither are within his contract - and I can see no reason for adding this to the already known and acknowledged liability of a carrier, without a single case or precedent to sustain it."'124

Although the authority of these cases to determine the outcome of Farwell's suit remained to be established, Loring chose a strategy not of challenge but of avoidance. Thus, in the case of the fellow servant ruling - which was actually the issue that the parties had agreed to place before the court for examination - he assumed that its general applicability would be affirmed and concentrated on arguing that it did not apply in this case. Similarly, although Moore had framed Farwell's suit as an action on the case, Loring assumed that, as elsewhere, the Mas- 
sachusetts court would be unwilling to give the employer's tort liability the expanded reading this required. Thus, he sought to avoid the problem by basing his argument on the contract between the railroad and Farwell. ${ }^{125}$

In attempting the removal of Farwell's case from beneath Lord Abinger's umbrella, Loring relied heavily on the circumstances of Farwell's working environment. The duties of the plaintiff, Loring told the court, were confined exclusively to running the locomotive and had nothing to do with the road itself or its condition. He was thus utterly dependent upon others for its proper construction and good condition. The plaintiff had sustained his injury by reason of the negligence of another person employed by the defendants to have charge of the switches whose duties were likewise peculiar and confined. Thus, whereas Priestley's case "was clearly one of equal knowledge on the part of the servant and of voluntary exposure on his part to a known hazard not required by his duty," Farwell just as clearly turned on the engineer's inability to know of the hazard of the open switch. Were the court to ignore the distinction and allow the principle contended for by the defendants, all persons employed by them in all their various departments - clerks, messengers, machinists, carriage builders, porters, ticket sellers - being employed for one ultimate purpose could be classed as servants together "and no one therefore could have any remedy against the defendants for the default of another, however distinct and independent might be their departments." Such an outcome, Loring told the court, was too absurd to contemplate.

Loring had, however, not merely to address the different circumstances of Priestley, but also Lord Abinger's all-encompassing rejection of the plaintiff's attempt in that case to infer a rule of employer liability upon which to sue. In this "interesting and peculiar" case, Loring continued, the court had undertaken to affirm a general rule of no liability applying to all cases of injury befalling a servant in the employment of his master without discrimination as to the particular nature of the employment relationship or the cause of the injury. In justification it had cited the master's causal remoteness from the injuries for which he might be made liable. Now remoteness per se was no argument against attributing liability, since carriers for hire and tavern or boardinghouse keepers were held responsible to parties suffering injury however remote the cause and however careful they personally might have been. Nevertheless, Loring accepted that there was no rule of law imposing obligations on employers in their relations with their employees analogous to those that imposed obligations upon carriers and tavern keepers. ${ }^{126}$ Rather, the question as to the duty of the master to care for 
his servant was one to be settled by reference to the nature of their contract. ${ }^{127}$

In construing contracts to determine the extent of the liability that the master had incurred, Loring argued the proper rule was that "the master contracts to be responsible to the servant for the carelessness or negligence of those employed by the master in distinct services or departments, over which the servant has no supervision or control." Thus in the example of the footman used by Lord Abinger, whose employment it was to tend at table and ride behind the coachman as the personal attendant of his master, and who had no care, control, or knowledge of the carriage or its equipment,

[I]t seems fair if not necessary to infer as the mutual understanding, that when the master contracts with the servant to ride upon his coach, giving him no right or authority to control it or to see to its sufficiency or equipment and no opportunity of doing so in the regular discharge of his duty, he contracts that he will have a coach which is safe to ride upon, so far at least as ordinary care on his part and those employed by him in that behalf is involved; for no one can suppose that a footman would enter upon such service with any other understanding. And as the knowledge and power in reference to the true condition of the carriage are entirely confined to the master or those employed by him and the footman has none, nor any means of obtaining them, it seems reasonable and just that the obligation in this behalf should be entirely upon the master."'28

This did not mean that the indemnity of the servant implied into the employment contract was absolute. Indeed, Loring continued, the same reasons that required the master to be held liable to the servant for injuries suffered by acts of those employed in different services over whom he had no control and against whose conduct he could not guard himself were just as persuasive in exonerating the master from liability in those cases where the servant could exercise control or supervision or had an opportunity to protect himself by caution and prudence. But in Farwell's case, no such control by the servant was possible. "Neither could interfere with the other nor even have any means of knowledge of the conduct or deportment of the other prior to the accident." The corporation, on the other hand, had complete power to control and supervise the switchman in the discharge of his duty ${ }^{129}$ and was actually under the most imperative obligation to exercise that power, for it owed a great and paramount duty to the world at large to keep the road in perfect order at all times.

Inevitably, Loring's notes of the case presented by the opposing counsel are briefer than those on his own. Nevertheless, together with the 
minutes of Chief Justice Shaw and Justice Hubbard it is sufficient to enable a detailed reconstruction of the defendant's arguments.

The plaintiff's claim, defendant's counsel stressed, was new and unprecedented. ${ }^{130}$ If allowed, it would bear adversely upon every person and company having others in their employ. The plaintiff claimed that he should be indemnified from danger resulting from the actions of all other servants employed by the defendants, save only those whose actions he could directly influence. The plaintiff, however, had not been employed to act alone but in conjunction with others. This was the nature of his employment. "To say that these persons were acting different parts and were therefore not acting jointly is a non sequitur: each was performing a different part, but for one object, and so they were fellow servants and copartners." 131 "Infinite mischief" - an avalanche of actions crippling employers in all walks of life-could be expected if the rule which plaintiff contended for was adopted. ${ }^{132}$

In order even to maintain an action, counsel stated, plaintiff had to establish his claim upon some rule of law. Being unable to find one his attorney had first sought to invent a principle whereby defendant could be charged with the ngeligence of another according to the maxim respondeat superior. The defendant's first answer to this was simply that no precedent could be found to support the application of the maxim in such circumstances. There was "not a single case where this principle has been applied to a case like the present" even though cases like this "must have happened in great numbers in the various trades." This absence of precedent "presses strongly against the plaintiff." 133

The defendant's second, and more important, response was that suits such as this one fell outside the ambit of the rule. Respondeat superior was a severe maxim, for it rendered the principal liable even though he was guilty of no personal misconduct. As such, the rule was an exception to the law governing relations between parties, one that had been created solely as a matter of policy to answer to the "convenience" and "general interest" of the public. Being thus an "artificial" rule "founded in wisdom" for "the benefit of society," it was pertinent to ask whether it was in the public interest for the court to entertain the extension of the rule in the manner called for by the plaintiff to the point where it assigned liability to the master for the acts of servants in reference to each other. ${ }^{134}$ Once examined from this perspective, it was plain that the public interest required that the servant should not have an opportunity to recover from the master, but rather that the several servants of the same employer should be treated as sureties for each other. Such would be the obvious intent of public policy in these circumstances, for the intent would be to supply "a strong motive to 
constant vigilance."135 By turning each servant into "a form of superintendent" accidents might be avoided, for "if they cannot look to the company [they] will better look out for each other."

Nor, finally, was there any support to be had for a suit such as this in public opinion, for while the legislature had recently taken action to underlie the duties owed by railroads to their passengers, its brief had not extended to employees. ${ }^{136}$ Although the plaintiff had argued that the general good would be served by the adoption of the principle for which he contended, therefore, it seemed clear that public opinion, judging at least by legislative action, was against him.

This discussion showed, defendant's counsel argued, that an action on the case founded on the principle of respondeat superior could not be maintained. Counsel for the plaintiff was apparently in agreement for, notwithstanding the original declaration, he had declined to maintain his action on the general principle of the master's liability for the torts of servants, effectively "conced[ing] that the plaintiff is not entitled in the principle respondeat superior." ${ }^{37}$ The case instead had been put wholly on the contract.

There was, however, no more an argument for plaintiff's contention considered as an action of contract than one of tort. What was the parties' contract? "To set in motion an engine-a movable machineon a fixed machine ... a single track rail road." ${ }^{138}$ Clearly the contract had been made in contemplation of the nature of the road and thus in the knowledge that there were turnouts with switches tended by switchmen whose character the plaintiff had ample opportunity to know by reason of his daily passage along the road. The plaintiff thus "makes a continuing contract applicable to the state of things which must arise on such employment." His contract "was made in reference to the labor and risk incident to the nature of the service" and with "a full knowledge thereof ... for a fixed and agreed compensation." In construing the contract to see what was implied, therefore, the true rule was that "the plaintiff takes upon himself the risks and perils incident to his situation" in exchange for "a satisfactory compensation." 139 If a master were to be held accountable to his servant in the exercise of care to any degree at all, it could be for nothing more than his responsibility to select and employ careful servants to act with the complainant. "And if such an one is employed, [the] superior is no further responsible." ${ }^{140}$ There could be no question that the defendant had not performed this duty "faithfully and fully." The servants the corporation had employed were fit and suitable - the switchman's general reputation was one of competence and care - and the road itself was in proper condition.

Loring's argument was notable primarily for its caution and its con- 
servatism. At only one point, when trying to explain the complete absence of precedents for claims by servants against masters under any circumstances, did he even hint that the plaintiff's suit afforded the court an opportunity for innovation. "The [defendant's] counsel says he has researched the library and that he nowhere found the protection of the servant alluded to."141 But the books in the library were "from a country where the distinction between master and servant in all its relations is very different from that here, [which] doubtless must affect judicial opinions as it does all society." In America, "a very different relation, and very different public sentiment prevails ... and requires a careful and equal distribution of the rights of protection and indemnity for the employed and the employer." ${ }^{42}$ But this was out of character, for Loring was certainly no radical. On the contrary, here, as elsewhere, the entire structure of his argument turned on a reverence for English precedent - he seemed almost mesmerized by Priestley v. Fowlerdictating a narrow focus on seeking individual exceptions to what he assumed to be well-established rules.

Given Loring's conservatism, in particular his effective abandonment of the action on the case in the face of Priestley and Murray, the result was a foregone conclusion. The plaintiff had accepted the premises of the defendant's argument and contested only the detail of the conclusions to be drawn from those premises. The court was not challenged to depart from those premises, and so it did not.

The general rule, Chief Justice Shaw indicated for the court, was one of no liability. As the defendant had maintained, and as plaintiff's counsel had himself conceded, there was no basis within the existing bounds of tort liability upon which such a suit might be maintained. The only possible candidate, respondeat superior, "presupposes that the parties stand to each other in the relation of strangers, between whom there is no privity. ... But this does not apply to the case of a servant bringing his action against his own employer to recover damages for an injury arising in the course of that employment" for, the parties not being strangers, "all such risks and perils as the employer and the servant respectively intend to assume and bear may be regulated by the express or implied contract between them, and ... in contemplation of law, must be presumed to be thus regulated." ${ }^{43}$ As to the construction of that contract, "the general rule ... is, that he who engages in the employment of another for the performance of specified duties and services, for compensation, takes upon himself the natural and ordinary risks and perils incident to the performance of such services, and in legal presumption, the compensation is adjusted accordingly." The court was "not aware of any principle which should except the perils arising from 
the carelessness and negligence of those who are in the same employment." $144 \mathrm{Had}$ such an exception been established by law "it would be a rule of frequent and familiar occurrence, and its existence and application ... would be settled by judicial precedents." But it was the court's opinion that no such exception had been established, "and the authorities, as far as they go, are opposed to the principle."145

Left at that, Shaw's decision would have amounted to little more than an affirmation of the sufficiency of the defendant's legal reasoning. As has been pointed out elsewhere, however, Farwell v. Boston \& Worcester was self-consciously a broad defence of the immunity of employers from liability for industrial injuries. ${ }^{146}$ The explanation for this lies in the "considerations of policy and general convenience" which, no less than legal principle, were cited by the court as determinants of its decision. ${ }^{147}$

As we have already seen, both parties to Farwell's case addressed the implications that decision of the suit one way or the other would have for the prevention of accidents. This was not an abstract debate but an issue of considerable moment. Take, for example, the accident record of the Boston \& Worcester Railroad in the four and one-half years that the case had been pending. All told, there had been twenty incidents: ten collisions (five at crossings); a derailment; one instance each of people and cattle killed while walking on the track; injury to four employees and two more killed; and some twenty-five passengers injured, twenty of these in a collision in June 1840 at Grafton. ${ }^{148}$ Even this sorry record was eclipsed, however, by the Boston \& Worcester's sister railroad, the Western. Beginning in the winter of 1840 , that road experienced a series of disasters that left seven employees dead and two injured, along with one passenger dead and at least another fifteen injured. ${ }^{149}$

The accidents on the Western Railroad resulted in the creation early on 18 January 1842 of a committee of inquiry by the state legislature. The committee was directed to investigate the causes of the accidents and to report on "the expediency of enacting such laws as will have a tendency to prevent a recurrence of similar accidents." The committee's interpretation of this task was that it should determine whether the railroad's agents were "chargeable with any negligence in the discharge of their duties, which should expose them to the censure of the public"; and whether "the expression of such censure by the Legislature" would "prevent the dangers which attend travel upon this and other similar roads." Its report of 18 February chose specifically to absolve the board of directors from any culpability. "We are not satisfied, from the investigations that we have been able to make, that the directors have 
been justly chargeable with any neglect of duty, which has caused these accidents." Rather, their management of the railroad was such as to inspire confidence. "They adopt the regulations which their judgment, aided by experience, pronounces best. They employ men whom they suppose to be the best qualified to discharge the duties required of them." Having found no evidence of any neglect on the directors' part "to use every reasonable precaution to prevent accidents," the committee declined to recommend any action "which may censure the directors in this matter." Nor, as a result of their confidence in the directors' management of the railroad, was the committee prepared to counsel legislative intervention. In what Stephen Salsbury has described as "a classic argument for an unfettered management," the committee earnestly expressed the hope "that increased vigilance and care will hereafter prevent the recurrence of the accidents which have so alarmed the community," but found itself unable to "suggest any legal enactment which can aid in producing this desirable result."150

Even had he had a mind to, it is unlikely that Shaw would have chosen to fly in the face of such a strong expression of legislative opinion on a matter of such pressing public concern. The public interest in railroad safety, the legislature had indicated, would not be served by the imposition of new responsibilities on management to care for the well-being of passengers and employees. ${ }^{151}$ Rather, the best means to the prevention of accidents was an unencumbered management, free to promulgate suitable rules and regulations to govern its business, free to pursue contraventions of those rules and regulations, and free to "discharge [any employee] from service, upon the slightest evidence of negligence, or wantonness, or incompetency." ${ }^{52}$ The public interest could thus be best served by the reinforcement of public confidence in managerial expertise and in the promotion of management's disciplinary capacity.

Shaw agreed. Considered in relation to the unspoken alternatives canvassed by the committee - the imposition of duties of care on employers through judicial or legislative intervention-his decision strongly endorsed the unfettered corporation. An employer was liable in tort to third persons for the negligence of his servant in the conduct of his business, but that was a strictly limited liability founded in policy rather than law and encompassing only those with whom the employer had no contractual relations. "Considerations of policy and general expediency forbid the extension of the principle, so far as to warrant a servant in maintaining an action against his employer for an indemnity which we think was not contemplated in the nature and terms of the employment, and which, if established, would not conduce to the general 
good." 153 Given that the relations between the parties were contractual, it was the contract that properly defined the extent and limits of the employer's responsibility. Where the contract contained no express warrant of indemnity for injury arising from the acts of other employees the court would not imply one, for in establishing the existence of implied terms in contracts between parties what a court did was to infer the existence of a duty on the basis of its consideration of what would best promote the benefit - "the safety and security" - of all persons concerned. No duty of care, such as would justify plaintiff's suit, was to be found following this route either. ${ }^{154}$

In endorsing the unfettered corporation, Shaw's decision in Farwell, like the report of the committee of enquiry just a few weeks before, also recognized and endorsed the structure of disciplinary power that permeated the employment relationship and yoked the public interest in industrial safety to its perpetuation. Indeed, Shaw went the committee one better, for his decision also invoked a responsibility on the part of employees to police themselves, holding that where, as here, "several persons are employed in the conduct of one common enterprise or undertaking ... the safety of each depends much on the care and skill with which each other shall perform his appropriate duty." Shaw proposed to take advantage of this interdependence by making each member responsible for potentially injurious negligence or misfeasance on the part of the others. "Each is an observer of the conduct of the others, can give notice of any misconduct, incapacity or neglect of duty, and leave the service if the common employer will not take such precautions, and employ such agents as the safety of the whole party may require." The incentive of each to take care and to ensure that others did likewise would, however, be destroyed if the employee could have resort to the common employer for indemnity in case of loss through injury. Hence the prospect of indemnity should be foreclosed. "By these means, the safety of each will be much more effectually secured, than could be done by resort to the common employer."'ss

In conjunction with the doctrine that an individual employee "assumed the risks" of his employment, this rather chilling conclusion placed all employees under the constant gaze of self-imposed or peerimposed discipline. As defendant's counsel had advocated, Shaw's decision turned each employee into "a form of superintendent," not only of others but also of self. ${ }^{156}$ These, of course, were responsibilities without concomitant power, for they were imposed within the context of a structure of managerial power that gave no role in the direction of the enterprise to the employees save that of policing conformity with promulgated rules and regulations. In contrast, the authority of the em- 
ployer over the direction of the enterprise-identified by Shaw implicitly and by the committee of investigation into the Western Railroad disasters explicitly as the sine qua non of an orderly and rational industrial environment - was power without responsibility, carrying with it no duty upon which the employee subjected to it could sue.

\section{Law and Power}

If Mechanism, like some glass bell, encircles and imprisons us ... yet the bell is but of glass; "one bold stroke to break the bell in pieces, and thou art delivered."157

Shaw's denial of a legal right of recovery threw Nicholas Farwell back onto the mercy of his employers. On 19 September 1842 the railroad's board of directors recorded that he had been paid $\$ 720$ in full of all claims against the corporation. This sum represented wages for the period from the date of the accident until the end of 1837 (approximately $\$ 120$ ), medical expenses (approximately $\$ 100$ ), and an additional sum of $\$ 500$ which had been voted to him by the board in January 1838 in response to his initial application for assistance. The directors could simultaneously congratulate themselves for maintaining their record of benevolent treatment of injured employees and for successfully avoiding the vastly larger expenses that a victory for Farwell's suit would have meant.

Succeeding cases in Massachusetts confirmed the reluctance of the courts to intrude any liabilities upon the state's employers. Thus in Hayes v. The Western Railroad Corporation (1849) and Albro v. The Agawam Canal Company (1850), ${ }^{158}$ the Supreme Judicial Court indicated that an employer was no more liable to an employee injured through the negligence of another employee who was either temporarily (Hayes) or permanently (Albro) in a position of authority over the injured employee than would have been the case had the two been fellow-servants of identical status. In King v. Boston \& Worcester Railroad (1851), it held that the employer could not be held liable for an injury caused by defective equipment, on the grounds that "keeping the road in proper repair... would seem to be the work of servants or laborers," the risk of whose negligence was assumed by the plaintiff. ${ }^{159}$ In Gillshannon v. Stony Brook Railroad (1852), it held that a laborer injured while being transported to his place of work on a gravel train could not recover against the employer because the transportation was a "permissive privilege" granted the plaintiff under his contract "to facilitate his labors and service" and was therefore included in his 
contract of employment. ${ }^{160}$ Finally, in Albro v. Jaquith (1855), it held that a servant injured by the negligence of another servant in the employ of the same master not only could not sue the master, she could not even sue the negligent servant. ${ }^{161}$

In light of the legal and social history of employee sickness and injury in the late eighteenth and early nineteenth centuries, it is not particularly surprising that the Massachusetts courts should so consistently have rejected claims of employer liability for injuries to their employees at work. This history must tend to qualify those accounts of the issue that place particular stress on Farwell as a decisive doctrinal innovation that "carved out an exception to the well-established rule of respondeat superior." 162 If anything, it shows that the true revolutionaries and innovators were not the judges who defined the fellow-servant rule but the plaintiffs who sought to press the new claim. ${ }^{163}$

Simply to assert that Shaw and his fellow judges reacted to the attempt to press claims of an employer's liability by refusing to depart from the status quo does not, however, do justice to their achievement. In a context of rapid social structural transformation, a refusal to innovate can be just as revolutionary in its effects as a dramatic policy shift (particularly where, as here, the refusal is articulated not in a piecemeal fashion but in the form of a broad rule). Here, in the context of severe social and economic stresses emerging from an industrialism predicated on the concentration rather than the diffusion of economic power and, more immediately, on a political economy of speed, the courts' refusal to innovate was a rejection of the possibility - and indeed of the desirability - of attempting to bring order to the social relations of employment through the mobilization of public authority to impose duties on employers, leaving the social and organizational structure of the new industrial "order" to be defined in terms of the employer's absolute authority.

The centrality of this approach to the trajectory being followed by the courts in the liability cases was rendered progressively clearer with each of the judgments successively reinforcing Farwell v. Boston \& Worcester described above. Always treating Farwell as their point of departure, these cases fleshed out the assumptions about the nature of industrial order - the social relations of production, the appropriate distribution and location of power and authority, the foundations of discipline - that had been embedded in the common-law doctrine of employer liability as a result of Shaw's ruling.

These were as follows: First, industry was the private domain of the employer, not amenable to public oversight. This argument, advanced by the defendant in Barnes but denied by the referees, had already been 
affirmed by Shaw in Farwell. It was underlined by the court in Hayes $v$. Western Railroad. There the defendant railroad corporation argued that the derailment in which the plaintiff had been injured had occurred because of the negligence of a fellow employee - a brakeman - who had been away from his post when the accident occurred. The plaintiff sought to have the trial court jury given leave to consider facts tending to show that the derailment had been caused by the negligence of the corporation in assigning too few brakemen to control the train. On appeal, the Supreme Judicial Court disallowed the plaintiff's contention. "When it is established, that the injury complained of was occasioned by the neglect of the man on the train, and not by reason of the absence of the man, then surely the absence of the man becomes immaterial ... The proximate cause is the object of inquiry, and when discovered, is to be regarded and relied on." The trial court had thus been quite correct to instruct the jury to disregard the question of whether there were enough brakemen, for this was not a matter appropriate for the jury to consider. "It was within the province and the duty of the court to instruct the jury, that a fault, if any, of the defendants, from which the plaintiff had not suffered, and of which he had no right to complain, was immaterial." 164

Second, employers might create hierarchies of supervision and control in order to project their authority within that private domain without rendering themselves liable for any adverse consequences suffered by their employees. Thus an employer might freely delegate power temporarily or permanently to officers to whom subordinates were required to show obedience on pain of dismissal, but would not be held accountable for the consequences of negligent actions on the part of those to whom it had delegated that supervisory authority. As the court put it in Albro v. Agawam Canal Company, "The injury of which the plaintiff complains appears to have happened while she was acting in the discharge of her duty to the defendants, as her employers, in their factory, and to have been occasioned by the negligence of another person [that is, the factory superintendent], who was also engaged in the defendant's service, in the same factory. The duties of the superintendent may be different, and perhaps may be considered as of a somewhat higher character than those of the plaintiff; [but] inasmuch as they are both the servants of the same master, have the same employer, are engaged in the accomplishment of the same general object, are acting in one common service, and derive their compensation from the same source ... [they] must be considered as fellow-servants." ${ }^{65}$

Third, the officers to whom power was delegated in a hierarchically organized enterprise were not to be held accountable in its exercise to 
their subordinates, but only to their superiors. Thus, courts in their decisions accommodated the distribution of power and the lines of accountability created privately by the employer. This was made abundantly clear in Albro v. Jaquith where, having failed in her attempt to hold the Agawam Canal Company liable for the actions of its superintendent, the plaintiff, Mary Albro, tried to sue the superintendent himself. She was told she could not. "His obligation to be faithful and diligent in this particular resulted either from an express contract with his principal, or is to be implied from the nature and character of the service in which he was engaged. And because this is the sole origin and foundation of his duty, he is responsible only to the party to whom it was due for the injurious consequences of neglecting it. It is not pretended that he had entered into any stipulation, or made any positive engagement with the plaintiff, in relation to the service which he had agreed to render to their common employer. She therefore had no legal right to complain of his carelessness or unfaithfulness; for he had made himself, by no act or contract, accountable to her." ${ }^{166}$

Fourth, following directly on Shaw's lead in Farwell, courts acknowledged that the exercise of supervisory power by the employer through the hierarchical structures created for that purpose was appropriately to be supplemented by the exercise of self- and peer-group superintendence on the part of the work force. Shaw having attempted to encourage work force self-superintendence by denying a right of recovery against the common employer, a lead followed by the courts in the subsequent cases, the court in Albro v. Jaquith sought to add further to the incentive by denying a right of recovery against the negligent peer - the immediate perpetrator - as well. "Many of the considerations of justice and policy, which led to the adoption of the general rule, now perfectly well established, that a party who employs several persons, in the conduct of some common enterprise or undertaking, is not responsible to any one of them for the injurious consequences of the mere negligence or carelessness of the others in the performance of their respective duties, have an equal significancy and force, when applied to actions brought for like causes by one servant against another." According to Justice Merrick, for the court, "the knowledge, that no legal redress is afforded for damages occasioned by the inattention or unfaithfulness of other laborers engaged in the same common work, will naturally induce each one to be not only a strict observer of the conduct of others, but to be more prudent and careful himself." By thus encouraging increased vigilance, "the welfare and safety of all" would be promoted. ${ }^{167}$

The influence on these judgments of such assumptions about the 
appropriate sources and conditions of industrial order is incontestable. Yet their presence was obscured because, as we have seen, the courts' rejection of the applicability of tort concepts meant that the issue of employer liability was dealt with within a contractarian doctrinal structure that, as Bob Gordon has suggested, represented the relationship between injured employee and defendant employer as "the product of voluntary individual choice." 168 Once the issue had been brought within this doctrinal category, the question of the actual allocation of power in the employment relationship was rendered irrelevant to the courts' determination of where responsibility for the occurrence of occupational injury should lie. Rather, questions about the allocation of authority and the imputation of responsibility in the employment relationship were translated into questions about the character of the agreement the individual parties, employer and employee, were held at some prior stage to have entered into, questions that courts would answer in the event of a dispute by having reference to that argreement - and with due regard to the civil liberties enjoyed by both parties as equivalent legal subjects - but with no glance to the actual structures of domination and subordination within which, as employer and employee, they moved. ${ }^{169}$ Thus construed, the employment relationship was rendered impervious to any attempt to invoke the existence of a structure of authority within the enterprise as justification for asserting the utility of building a commensurate structure of protective or compensatory duties. Instead the courts' presumption "that employees understand and appreciate the ordinary risk and peril incident to the service in which they are to be employed" and that they "predicate the compensation they are to receive, in some measure, upon the extent of the hazard they assume," made the exercise of power in the employment relationship a thoroughly mysterious affair. ${ }^{170}$

\section{Conclusion}

In the introduction to this paper, I stated that my objective was a more plausible explanation than those so far developed by labor or legal historians of the relationship between court decisions limiting employer liability in industrial accident cases and the particular form that industrial capitalism was taking in the United States by the middle decades of the nineteenth century. To fill the bill, such an explanation must clearly address the question of the part played by law in the process of capital accumulation. The essence of that process is the unending struggle of employers of labor to secure profit through the physical orga- 
nization and reorganization of the process and technology of production, and in particular, through the exercise of disciplinary power over their employees. ${ }^{171}$

In attempting the former - the organization and reorganization of production - the employer asserts a power grounded in the right to exclusive control of his property (i.e. the means of production). The role he seeks from law, if he is to be successful, is the relatively unproblematic and essentially negative one of guarantor. ${ }^{172}$ In attempting the latter - the assertion of disciplinary power-the employer makes a rather more extensive bid for legal aid, for although in the legal recognition of possession as the power to exclude one may recognize the existence of a necessary condition for the creation of relations of domination between individuals, possession by itself is not sufficient to guarantee the successful reproduction of such relations within the work process. Success here requires in addition recognition of the employer's claim to act as a private legislator. It is here, in its relation to the attempts by employers of labor to exercise a power to discipline as well as a power to exclude, that the key to law's role in the process of capital accumulation lies. ${ }^{173}$

Some years ago, the nature of this relationship was explored briefly but suggestively by Michel Foucault. The claim to a monopoly of rule on the part of the state conveyed by the theory of sovereignty, Foucault argued, had resulted - so far as the analysis of power was concernedin the reduction of all power relations to relationships involving the state. ${ }^{174}$ Disciplinary power, however, was "a non-sovereign power, which lies outside the form of sovereignty" and which could not be attributed to or deduced from any theory of sovereignty. ${ }^{175}$ The practical effect of the state's claim, and of the juridical discourse and legal practices in which it was expressed, had thus been to obscure the sources of disciplinary domination. The language Foucault uses suggests a conspiracy - "A system of right [has been] superimposed upon the mechanisms of discipline in such a way as to conceal its [sic] actual procedures, the element of domination inherent in its techniques, and to guarantee to everyone, by virtue of the sovereignty of the State, the exercise of his proper sovereign rights" - but this is deceptive. Foucault does not argue that it is law's function to justify or explain the exercise of disciplinary power: law's role is to articulate the immanent rationality of sovereign power; the mechanisms of discipline have their own explanatory discourses which simultaneously articulate the immanent rationality of disciplinary power in its various manifestations. Rather the mechanisms and discourses of law and of discipline exist simultaneously. "Modern society, then from the nineteenth century up to our own day, has been 
characterized on the one hand, by... [a discourse] based on public right, whose principle of articulation is the social body and the delegative status of each citizen; and, on the other hand, by a closely linked grid of disciplinary coercions whose purpose is in fact to assure the cohesion of this same social body." Together, the right of sovereignty and the mechanism of discipline interact and intersect in severally defining "the arena in which power is exercise."176

The question whether employers should be made liable for the consequences of industrial accidents is a concrete example of this interaction and intersection. As we have seen, industrial accidents began to occur in increasing numbers in the late 1830 s, largely as a consequence of employers' attempts to increase the intensity of the accumulation process. Suits seeking to attribute responsibility for work injuries to employers and to compel them to pay substantial sums in compensation threatened a significant level of legal regulation of the employer's capacity to exercise power over his employees. In the circumstances of the particular "moment" at which this interference was mooted, circumstances of crisis in and challenge to the intensification of the accumulation process, the refusal of courts to admit the possibility of intervention indicated that the contested territory of production was for occupancy by the employer's disciplinary power and not by the state.

Turning aside challenges from employees was, however, only one aspect of this particular intersection of law and disciplinary power. Of no less importance was the painstaking doctrinal exegesis-the discursive elaboration of the immanent rationality of sovereign powerthrough which the courts sought to reassure those appalled at the "mysterious" power of employers to crush "humble industry" without redress of the lawfulness, indeed the justice, of such outcomes. In this aspect, the courts reveal themselves as central actors in the reproduction of the social order, creators of representations of contemporary life that make the present "usable" by imparting to what is merely contingent a powerful aura of certainty. ${ }^{177}$ In the case of industrial accidents, the present the courts assisted to prevail was one in which the maiming or death of employees at work could be treated as part of the social landscapea routine, if regrettable, occurrence that was part of the price society paid for the possession and exercise of the rights and liberties, such as freedom of contract, that were the attributes of free and equal citizens. Thereby the courts helped to render the structure of power that lay behind and effected such outcomes not merely mysterious but in fact virtually invisible. 


\section{NOTES}

Versions of this essay have been presented to faculty seminars at The Johns Hopkins University, Washington University in St. Louis, and the University of New Hampshire, and also to the Organization of American Historians 80th Annual Meeting (Philadelphia, 1987). I am grateful to all who participated in these sessions for their suggestions.

I am indebted to Willy Forbath, Staughton Lynd, Pat O'Malley, Adrian Howe, Kit Carson, and Tony Blackshield for their comments and suggestions along the way.

I would also like to express my gratitude to the following individuals and institutions for their assistance in expediting the research on which this article is based: Edgar J. Bellefontaine and the staff of the Social Law Library, Boston; Giuseppe Bisaccia and the staff of the Rare Books and Manuscripts Division, Boston Public Library; Florence B. Lathrop and the staff of the Manuscripts and Archives Division, Baker Library, Harvard Business School; and Catherine Menand and the staff of the Judicial Archives Reclamation Project, Suffolk County Court House, Boston.

Finally, I wish to acknowledge the support of the Charles Warren Center, Harvard University; the American Bar Foundation; the Australian Research Grants Committee; and the School of Social Sciences, La Trobe University, all of whom have granted assistance to the larger project of which this article is a part.

1. Shattuck to Hale, in Barnes v. Boston \& Worcester Railroad Corp., Charles Greely Loring Papers, unprocessed manuscript collection, Social Law Library, Boston (hereinafter cited as Loring Papers).

2. These and all subsequent details of the case are drawn from files of case notes and testimony referring to Barnes v. Boston \& Worcester Railroad Corp. in Loring Papers.

3. Moore to Hale, in Loring Papers. For Shattuck's letter to Hale see the prologue to this paper.

4. Barnes v. Boston \& Worcester Railroad Corp., Suffolk County Court of Common Pleas, October term 1837 (New Entry 216). (These records are currently in the care of the Judicial Archives Reclamation Project, Suffolk County Court House, Boston, hereinafter referred to as JARP.)

5. Supreme Judicial Court dockets, March term 1838 (Continuing Action 313) and March term 1839 (Continuing Action 172). In Office of the Clerk of Court, Supreme Judicial Court (Single Justice Session), Suffolk County Court House, Boston.

6. For a full listing see Comment, "The Creation of a Common Law Rule: The Fellow-Servant Rule, 1837-1860," University of Pennsylvania Law Review 132 (1984): 579-620.

7. Farwell v. Boston \& Worcester Railroad Corp., Suffolk County Court of Common Pleas, October term 1839 (New Entry 150), JARP.

8. Leonard W. Levy, The Law of the Commonwealth and Chief Justice Shaw (Cambridge, 1957), 166. See also, Lawrence M. Friedman and Jack Ladinsky, "Social Change and the Law of Industrial Accidents," Columbia Law Review 67 (1967): 50-82.

9. See, for example, Morton J. Horwitz, The Transformation of American Law, 1780- 
1860 (Cambridge, 1977), 208-10. See also Comment, "Creation of a Common Law Rule," 580-81. It would be less than fair to Horwitz if I did not add that although, as will become apparent, I disagree with his rendition of the doctrinal dynamics of the fellow-servant rule, as will also become apparent, I have benefitted enormously from his general discussion of the pivotal role of commercial and industrial elites in the development of antebellum Massachusetts's legal culture. I am grateful to Willy Forbath for helping me clarify my thinking on this matter.

10. Robert L. Rabin, "The Historical Development of the Fault Principle: A Reinterpretation," Georgia Law Review 15 (1981): 925-61. See also Gary T. Schwartz, "Tort Law and the Economy in Nineteenth Century America: A Reinterpretation," Yale Law Journal 90 (1981): 1717-75; M. J. Pritchard, Scott v. Shepherd (1773) and the Emergence of the Tort of Negligence (London, 1976).

11. On subsequent doctrinal debates on the meaning and application of the fellowservant rule, see Comment, "Creation of a Common Law Rule," 594-620. See also Lawrence M. Friedman, A History of American Law (New York, 1973), 422.

12. Robert W. Gordon, "Critical Legal Histories," Stanford Law Review 36 (1984): 1122. (Emphasis in original).

13. Thomas Carlyle, "Signs of the Times," in Carlyle: Selected Works, Reminiscences and Letters, ed. Julian Symons (Cambridge, 1963), 22.

14. Leo Marx, The Machine in the Garden: Technology and the Pastoral Ideal in America (New York, 1964), 170-80.

15. Carlyle, "Signs of the Times," 22-23, 25.

16. Ibid., 35.

17. Quoted in George S. White, A Memoir of Samuel Slater (Philadelphia, 1836), 53-57.

18. For an interpretation of the manifestation of such sentiments in law, see James Willard Hurst, Law and the Conditions of Freedom in the Nineteenth Century United States (Madison, 1956), 3-32.

19. Marx, Machine in the Garden, 181.

20. Joyce Appleby, Capitalism and a New Social Order: The Republican Vision of the 1790s (New York, 1984), 49-50.

21. Drew McCoy, The Elusive Republic: Political Economy in Jeffersonian America (Chapel Hill, 1980), 15, 62-67.

22. John Kasson, Civilizing the Machine: Technology and Republican Values in America, 1776-1900 (New York, 1976), 3-51, especially 13; Marx, Machine in the Garden, 145-50.

23. McCoy, Elusive Republic, 111, 104-19. A particular object of concern for those sharing this perspective was Alexander Hamilton's 1791 blueprint for industrial growth, the Report on Manufactures. Hamilton's Report underscored how an industrialism animated by the political economy of Federalism would be a far different phenomenon from that implied in the Jeffersonian vision, seeming to many liberal Republicans "to describe a society ominously reminiscent of the English system." Rather than a republican industrialism predicated on the diffusion of wealth and energy, the Report recommended policies to encourage the concentration of capital and its investment in large-scale manufacturing through the creation of subsidized corporate monopolies. To Hamilton's opponents, these "artificial" monopolies "would ruin private, 'natural' producers and foster dangerous, unrepublican disparities in wealth." Indeed, many of them "came to fear nothing less than a conspiracy to corrupt American society and smash the republican experiment by imitating British forms, manners and institutions." This same contest of world views was renewed ten years later when the revival of commercial 
tensions between America and Europe brought Congress "a deluge of petitions seeking public support of domestic manufactures." Shrugging off bitter Federalist criticism, the Jeffersonians rejected the petitions, pointing the "excellent and extensive" achievements of the artisan trades and treating the virtual absence of larger-scale factory production of textiles and metal goods as a positive good. "We may felicitate ourselves that, by reason of the ease of gaining a subsistence and the high price of wages, our fellowcitizens born to happier destinies are not doomed to the wretchedness of a strict discipline in such manufactories." See also McCoy, Elusive Republic, 148-65, 223-24.

24. See generally Appleby, Capitalism and a New Social Order, 79-105.

25. Ibid., 45, 3-23.

26. Ibid., 94.

27. See, in general, Rowland Berthoff, An Unsettled People: Social Order and Disorder in American History (New York, 1971).

28. Kasson, Civilizing the Machine, 31-32.

29. Ibid., 64. See generally, David J. Rothman, The Discovery of the Asylum: Social Order and Disorder in the New Republic (Boston, 1971).

30. Thus Michael Ignatieff notes that Bentham conceived of the penitentiary "as a machine for the social production of guilt." A Just Measure of Pain: The Penitentiary in the Industrial Revolution, 1750-1850 (London, 1978), 213.

31. Quoted in ibid., 67.

32. Rothman, Discovery of the Asylum, 108; Ignatieff, Just Measure of Pain, 67.

33. See, for example, Sidney Pollard, The Genesis of Modern Management: A Study of the Industrial Revolution in Great Britain (London, 1965). The same assumption animates Alfred D. Chandler's The Visible Hand: The Managerial Revolution in American Business (Cambridge, 1977).

34. Ignatieff, Just Measure of Pain, 62.

35. Kasson, Civilizing the Machine, 64.

36. Anthony F. C. Wallace, Rockdale: The Growth of An American Village in the Early Industrial Revolution (New York, 1978), 263.

37. Ibid., 57-86. Indeed, according to Andrew Fraser, what one sees represented in the early business corporation is not at all the budding capitalist's exclusive focus on profits and production but a traditional elite's political concern for an institutional form to underpin the natural hierarchical order of propertied authority in the face of the ravages of Jeffersonian democracy. As much a political as an economic institution, the early corporation was "a little republic," whose relationship with its employees-that of "benevolent but firm patriarch[y]"- reflected a conservative republican communitarian ideology. See Fraser, "The Corporation as Body Politic," unpublished paper, 2959.

38. Kasson, Civilizing the Machine, 69-86; Jonathan Prude, The Coming of Industrial Order: Town and Factory Life in Rural Massachusetts (New York, 1983), 111-16; White, Memoir of Samuel Slater, 113-20.

39. As Keith Tribe puts it in his own critique of this representation, when we think of the Industrial Revolution we think "of factories and steam power, of fat capitalists and impoverished wage workers," and above all "of machinery, discipline, and regulation." See Tribe, Genealogies of Capitalism (London, 1981), 111.

40. Walter Licht, Working for the Railroad: The Organization of Work in the Nineteenth Century (Princeton, 1983), 79. See generally, E. P. Thompson, "Time, WorkDiscipline and Industrial Capitalism," Past and Present 38 (1967): 56-97.

41. Wallace, Rockdale, 181; Kasson, Civilizing the Machine, 78. See also Thomas Dublin, Women at Work: The Transformation of Work and Community in Lowell, 
Massachusetts, 1826-1860 (New York, 1979), 70-71; Carl Siracusa, A Mechanical People: Perceptions of the Industrial Order in Massachusetts, 1815-60 (Middletown, Conn., 1979), 115.

42. Dublin, Women at Work, 60, 73.

43. Barbara M. Tucker, Samuel Slater and the Origins of the American Textile Industry, 1790-1860 (Ithaca, 1984), 147-62; Prude, Coming of Industrial Order, 130.

44. Richard C. Edwards, Contested Terrain: The Transformation of the Workplace in the Twentieth Century (New York, 1979), 23-27.

45. Tribe, Genealogies of Capitalism, 115. Note the experience of the early-eighteenth-century English ironmaster, Ambrose Crowley. Crowley had attempted to run his works according to rules "defining duties, compensations, and penalties in the minutest detail." When it came to the actual operation of his works, however, Sidney Pollard tells us that he was soon reduced to "a constant sense of despair about the efficiency of control." Genesis of Modern Management, 55-59. Pollard concludes that the modern industrial proletariat that emerged in England in the first half of the nineteenth century experienced not so much disciplined regularity as "compulsion, force and fear" (207). For a sense of the chaos of industrialism in England, see Raphael Samuel, "The Workshop of the World: Steam Power and Hand Technology in Mid-Victorian Britain," History Workshop 3 (1977): 6-72.

46. This point owes much to Michel Foucault's pointed observation that a disciplinary society does not imply a disciplined society; or, in other words, that disciplinary "simply refers to the deployment of certain techniques rather than to the achievement of desired effects as well." See Mark Cousins and Athar Hussain, Michel Foucault (London, 1984), 188. Rothman implies a similar conclusion in testifying to the inability of prisons and asylums, behind their respective institutional facades to achieve "order" in their populations. See Discovery of the Asylum, 237-64. See also Ignatieff, Just Measure of Pain, 207-15.

47. Alf Ludtke, "The Historiography of Everyday Life: The Personal and the Political," in Culture, Ideology and Politics: Essays for Eric Hobsbawm, ed. Raphael Samuel and Gareth Stedman Jones (London, 1982), 48. Walter Licht comments on railroad work: "Employment was erratic and uncertain, and the hours were long. But an even greater specter haunted nineteenth-century American railwaymen. Railroad work was dangerous. Accidents were not just common; they were an integral component of the work. If many men ultimately escaped accidental injuries and death, the fear and threat of such happenings were inescapable and hung over everyone working on the line." In Working for the Railroad, 181.

48. Reports 100 (3 May 1827); 210 (4 July 1829); 1026 (2 April 1849); and 1247 (19 June 1851), all in Suffolk County Coroners, Reports of Inquests, Adlow Collection, Rare Book Room, Boston Public Library.

49. Quoted in Siracusa, Mechanical People, 157.

50. By "industrial accident" I mean an injury or illness occurring within the scope of employment and causally linked to employment.

51. Thomas Dublin makes passing reference to "the risk of personal injury" attending particular mill occupations, but provides no details. Women at Work, 65. In Rockdale, 149-50, Anthony Wallace argued that industrial accidents were a common occurrence, but that assertion is based on nothing more than a few incidents recorded by the artist John Rogers while he was a journeyman machinist in the early 1850s. Wallace has pursued the issue more systematically in St. Clair: A Nineteenth Century Coal Town's Experience with a Disaster-Prone Industry (New York, 1987), particularly 249-75. In this book, however, his evidence is drawn mostly from the 1860 s and 1870 s. Walter 
Licht's excellent study, Working for the Railroad, pays considerable attention to accidents but unfortunately he also has little concrete to offer on the earlier period.

52. Simeon Farmer, who "had his leg broke in two places by the return of an iron crow bar in turning over a stone" in June 1797; Richard Briggs "who had his leg broke blowing stones" in September 1800; and one Mr. Malseed who was fatally injured when he fell into a lock pit in August 1804. In Baldwin Papers, Box 2, "Reports"; and James F. Baldwin to Loammi Baldwin (13 August 1804), Baker Library, Harvard Business School, Box 1.

53. A laborer, Martin Nolan, had been injured while engaged in digging the drains from the new court house to the adjacent street. "The earth caved in upon him, and so injured him in the limbs as to confine him to his house fourteen weeks." Bulfinch to - - ( ), in Adlow Collection.

54. Loammi Baldwin, Jr., to Commodore John Rogers, President of the Navy Board (2 November 1831), in Baldwin Papers, Box 21; Dexter to Baldwin (11 February 1833), in Baldwin Papers, Box 19.

55. In the absence of a reliable and comprehensive statistical record, any statement about the frequency of industrial accidents during the first half of the nineteenth century must be treated as at best conjectural. The hazards of relying on employer records are especially obvious, given that for much of the first three decades of the nineteenth century in Massachusetts the notion of employment remained sufficiently ephemeral to preclude the development of any widespread sense of an employer's responsibility for employees. Wage labor was the exception rather than the rule, and those who performed labor for others (outside the patriarchal household of family, domestic servants, and apprentices) did so more often as self-employed, independent contractors serving customers than as employees. This tended to disengage the employer from the manner in which work was performed and therefore from any mishap which occurred during its performance. Even where wage labor was common, as in the construction trades, employers took steps to limit their involvement in large-scale direct employment of labor. Rather than create its own semi-permanent work force, for example, the Middlesex Canal Corporation attempted to subcontract most of the unskilled construction work to local farmers or to gangs of laborers who formed themselves more or less spontaneously to bid for digging by the road. Skilled work, particularly masonry, was also usually subcontracted to master artisans who supplied their own journeymen and assistants. Delays in completing sections of the work were often attributed to the absence of a pool of labor on call, but the practice of subcontracting had the valuable benefit of spreading the economic risks associated with the enterprise beyond the investors in the corporation. These forms of work organization make accidents particularly difficult to trace because there is no reason why injuries to employees of subcontractors or to members of gangs of laborers would show up in the primary contractor's records. Indirect confirmation of this can be gleaned from a letter from George Whistler, chief engineer of the Western Railroad Corporation, to the corporation's board in answer to a claim made by Elias Whipple of Springfield for compensation for the death of his son in a construction accident. The son, Whistler indicated, "was unfortunately killed while on the road as a hired laborer of the contractor ... it has never been the custom elsewhere to my knowledge, for Railroad corporations to make provision, in cases of accident among these laborers." See Whistler to the President and Directors, Western Railroad Corporation (8 June 1841), WRR Case 1, Clerk's Files. In Edward J. O'Day, "Constructing the Western Railroad: The Irish Dimension," Historical Journal of Massachusetts 11 , no. 1 (January 1893): 20-21.

56. Suffolk County Coroners, Reports of Inquests 230-1595, in Adlow Collection. 
57. Ibid., $180,212$.

58. Of twenty-five railroad workers whose deaths in accidents were recorded by the Suffolk County coroners between June 1845 and January 1859, eleven were brakemen. The next largest category was yardmen, with five (see Reports of Inquests in Adlow Collection). Over the same period on the Boston and Worcester alone, eight brakemen were killed and four injured. After one particularly nasty incident in January 1848 , the directors appointed a committee to report on the cost of raising all bridges on the line. There is no indication, however, that any further action was taken. Boston and Worcester Railroad, Directors' Minutes, Vol. 6 (meeting of 4 January 1848), in Boston and Albany Railroad Collection, Baker Library, Harvard Business School.

59. Charles F. Sabel, Work and Politics: The Division of Labor in Industry (New York, 1982), 199. See also W. G. Carson, The Other Price of Britain's Oil: Safety and Control in the North Sea (Oxford, 1982).

60. Dexter to Baldwin (14-28 January 1833), all in Baldwin Papers, Box 19.

61. Suffolk County Coroners, Reports of Inquests 753 (24 December 1845), in Adlow Collection.

62. Carson, Other Price of Britain's Oil, 84-138.

63. Dublin, Women at Work, 108-12, 132-38. (Emphasis supplied.)

64. Tucker, Samuel Slater, 214-49. And see generally Siracusa, Mechanical People, $160-61$.

65. Stephen Salsbury, The State, The Investor and the Railroad: The Boston and Albany, 1825-67 (Cambridge, 1967), 64-65.

66. Ibid., 109.

67. Ibid., 112. So desperate was the board to demonstrate profitability that it committed itself to a first dividend that exceeded earnings by $\$ 5,000$. As Salsbury comments "In effect, the [board] proposed to pay out as a dividend the money the stockholders paid in as capital" (130). Not to be outdone, the board two years later declared a halfyear dividend of 3 percent, which it proposed to finance by raising a loan. Boston and Worcester Railroad, Directors' Minutes, Vol. 2 (meeting of 20 June 1837).

68. Salsbury, The State, the Investor and the Railroad, 114-15.

69. Examination of the directors' minutes indicates that in operations through 1850 , the railroad's superintendents reported thirty-two incidents in which trains were derailed or involved in collisions with each other, and a further nineteen collisions with road traffic at crossings or with straying cattle. Over the same period some forty employees were reported killed or injured, along with forty-nine passengers and twenty-two pedestrians who had strayed onto the tracks. Boston and Worcester Railroad, Directors' Minutes, Vol. 1-7. (See also Suffolk County Coroners, Reports of Inquests.) It is likely that these figures understate the full total of death and injury as the superintendents did not always offer full details of the incidents they reported.

70. Directors' Minutes, Vol. 3 (meetings of 16 January 1839 and 10 April 1839).

71. Report of the Committee of Stockholders appointed "to examine and consider the report of the directors," in Boston and Albany Railroad Collection, Case 6.

72. For a description of this growing consciousness of crisis in Massachusetts see Siracusa, Mechanical People, 155-62. See also generally David M. Gordon, et al., Segmented Work, Divided Workers: The Historical Transformation of Labor in the United States (New York, 1982), 54-78.

73. See, for example, Wallace, Rockdale, 326-37; Tucker, Samuel Slater, 223-29: As Licht shows, this was a particular strategy of railroad managers faced with the accumulation of intractable operating problems. Working for the Railroad, 80-89.

74. Thus when, early in 1842 , the Committee on Rail-roads and Canals of the 
Massachusetts General Court mounted an investigation into "the causes of the frequent accidents upon the Western rail-road" it determined that the most notorious accidenta head-on collision on 5 October 1841 at Westfield - had been caused by the failure of one conductor to keep to his timetable. However, in investigating a second major accident that had occurred in early February 1842 at Richmond, the committee professed itself unable to explain why an engineer (killed in the accident) had run his locomotive through a damaged section of track at normal speed (causing it to derail) without pausing to consider the impact on train crews of injunctions from the corporation to stick rigidly to the timetable on pain of dismissal. See Commonwealth of Massachusetts, Senate Document 55 (February 1842), 5-8.

75. See above, note 50 and accompanying text.

76. As Charles Sobel has pointed out, "rules are supposed to be constructed so carefully that following them blindly produces a perfect product every time. But ... in factories as elsewhere, reality is so complex and rapidly changing that no plan can be comprehensive enough to be a completely reliable guide to action." Work and Politics, 104. Similarly, Craig Littler states that "simple models of an organizational structure which assume unilateral rule-determination and unilateral rule-enforcement are extremely simplistic." Littler stresses how rule evasion can quite easily become acceptable behavior to management and how this "collaborative violation" becomes "stabilized as a permanent aspect of the work organization." Craig R. Littler, The Development of the Labor Process in Capitalist Societies (London, 1982), 40-41. See also Michael Burawoy, Manufacturing Consent: Changes in the Labor Process Under Monopoly Capitalism (Chicago, 1979), 46-94.

77. Licht, Working for the Railroad, 89-93.

78. Kasson, Civilizing the Machine, 86-97.

79. Dublin, Women at Work, 112. Their efforts bore fruit in 1845 with the appointment of an investigative committee by the state legislature, before which textile workers presented compelling evidence of the "pain, disease, and privation" attending mill work and of the necessity of reducing hours. The committee, however, declined to recommend legislation and invited the operatives to make their representations to their employers who were in the best position to judge what remedies to institute. See Caroline Ware, The Early New England Cotton Manufacture: A Study in Industrial Beginnings (Boston, 1931), 251; Dublin, Women at Work, 113-15.

80. Carlyle, "Signs of the Times," 41.

81. These and all subsequent details of the case taken from case notes of Barnes $v$. Boston \& Worcester Railroad Corporation in Loring Papers.

82. "He was in the habit of taking very full notes at the trial of his cases, and of writing out his arguments - generally by dictation - almost at length." Theophilus Parons, Memoir of Charles Greely Loring, Prepared Agreeably to a Resolution of the Massachusetts Historical Society (Cambridge, 1870), 9.

83. Emphasis in original.

84. Rex v. Inhabitants of Christchurch (1760), Burrow's Settlement Cases 494; Rex v. Inhabitants of Wintersett (1783) Clad. 298. See also Dominus Rex v. Inhabitantes de Hales Owen (1717) 1 Strange 100, concerning a master's obligation to his apprentice. Dalton's Countrey Justice (London, 1742) states at page 141, "If a servant, retained for a year, happen within the time of his service to fall sick, or to be hurt or lamed, or otherwise to become non potens in corpore, by the Act of God, or in doing his master's business; yet the master must not, therefore, put such servant away, nor abate any part of his wages for such time."

85. Servants or employees crippled or injured in accidents occurring in the course 
of their employment were "casual poor," the responsibility of the parish in which the accident occurred (on the principle that responsibility under the poor laws lay with the parish where the pauper "really became poor and impotent by being disabled there." Lamb v. Bunce (1815) 4M. \& S. 276. See also Simmons v. Wilmott (1800) 3 Esp. 91; Rex v. Kynaston (1800) I East 117. While disputes over the relief of injured servants were not an uncommon occurrence in English courts, therefore, they were almost invariably disputes among parishes over attempts to "export" injured paupers or actions brought by surgeons and apothecaries against parishes to recover attendance fees. See, for example, Rex $v$. Inhabitants of St. James in Bury St. Edmunds (1808) 10 East 26; Wing v. Mill (1817) I B. \& Ald. 104; Rex v. Inhabitants of St. Lawrence, Ludlow (1821) 4 B. \& Ald. 660; Tomlinson v. Bentall and Another (1826) 5 B. \& C. 738. No action appears to have been brought by a servant against a master for medical expenses and relief prior to Priestley v. Fowler (1837) 3 M. \& W. 1. See, however, Sellen v. Norman (1829) 4 Car. \& P. 80; Cooper v. Phillips (1831) 4 Car. \& P. 580; Regina v. William Smith (1837) 8 Car. \& P. 151. For an excellent summary of the law in England prior to Priestley v. Fowler, see Brian W. Napier, "The Contract of Service: The Concept and its Application" (Ph.D. diss., University of Cambridge, 1975), 129-35.

86. 2 Esp. 739, 4 Dougl. 284.

87. 1 Esp. 270.

88. 3 Bos. \& Pul. 247. It is worth noting the comments of Alvanley's brother judges. Justice Heath considered it was to the advantage of servants that the legal claim for assistance should be against the parish rather than against their masters, "for the situation of many masters who are obliged to keep servants, is not such as to enable them to afford sufficient assistance in cases of serious illness." Similarly, Justice Rooke concluded that if the general principle contended for the plaintiff were to be adopted as a rule of law, "many persons who are obliged for the purpose of their trade, to keep a number of servants, would be unable to fulfill the duty imposed upon them by the law."

89. Nathan Dane, A General Abridgement and Digest of American Law, 9 vols. (Boston, 1823), 2:319.

90. 14 Mass. 448.

91. Littleton v. Tuttle is reported at 4 Mass. 128. See also Inhabitants of Winchendon v. Inhabitants of Hatfield (1808) 4 Mass. 122; Inhabitants of Andover v. Inhabitants of Canton (1816) 13 Mass. 546; and Inhabitants of Stockbridge v. Inhabitants of West Stockbridge (1815) 12 Mass. 399 and in review (1817) 15 Mass. 256.

92. Although it is not directly on the point, the following observation drawn from Dane's Abridgement sheds light on the basis of the distinction between a master's responsibilities to a slave or juvenile servant and his responsibilities toward a hired laborer. "If a slave or a servant, in the place of a child, be beaten or injured by a third person, and sickness, \&c. follows, the master recovers for the whole loss, as he must pay the expense, and lose the servant's time; but not where his hired servant has been beaten, for then he bears the loss, and is not entitled to wages during the time he is disabled by the battery, and he finally pays the expense, and such expense will be part of the damages he will recover." $1: 315$.

93. 19 Mass. 451.

94. According to Dane, "The master of an apprentice is bound to pay for medical attendance on the apprentice, from the very nature of the relation between master and apprentice, and the father of the apprentice is only bound, when the services have been rendered at his request." Dane emphasized the contrast with nonindentured labor. "As to hired servants, the employer is not bound to pay for medical attendance." Abridgement, 9:35-36. 
The provisions of the laws of settlement applying to the maintenance of indigent apprentices reinforce the conclusion that the legal responsibilities of the master to sick or injured apprentices were derived from a specific responsibility levied on masters to act in loco parentis, rather than from any general residual rights of servants. Unlike slaves, whose legal status denied them the right to a settlement of their own, apprentices did not acquire a derivative settlement through their masters but instead had their own settlement through their parents. This meant that where the maintenance of an apprentice was thrown into doubts by the pauperization of his master, the indenture was annulled and responsibility for care reverted to the apprentice's parents and thus ultimately to the community where they had their settlement. Prior to 1794, an apprentice deprived of maintenance by the death of his master could become the responsibility of the master's estate, to be maintained by the estate's executor until such time as his indenture was reassigned or the parties to the indenture agreed that it should be annulled. After 1794, however, the indenture was held to be annulled automatically by the master's death and the apprentice was returned to his parents or to the overseers of the poor to be bound out afresh. See The American Justice (an abridged edition of Burn's Justice of the Peace) (Dover, N.H., 1792), 34-36; Mass. Stat.s (1793) c. 59, (1794) c. 64.

95. In his classic Government and Labor in Early America (Boston, 1981), Richard B. Morris notes that in the case of indentured servants, as with slaves and apprentices, it was colonial policy to hold masters responsible for their welfare (18). Employers had no liability for unbound labor, however, the burden falling by default upon the town (in the case of Massachusetts) in which the accident or sickness occurred. Where the injured party was a stranger, the town would then attempt to determine where the injured person's settlement was and seek reimbursement. This was often a hopeless task, as is evidenced in the following petition of the Selectmen of the Town of Palmer (24 January 1767), Massachusetts Archives Collection, vol. 303, 128:

To His Excellency Francis Bernard Esq., Captain General and Governor in Chief over His Majesties Province of the Massachusetts Bay in New England \&C, and to the Honorable His Majesties Counsell. The petition of William Scott, Seth Shaw and Robert Roggers, Selectmen and overseers of the poor of the District of Palmer Humbly sheweth. viz

That whereas one John Ryan, a Transient person not being an inhabitant of our District, nor having any regular place of abode in America that we know of: as he was passing threw our District was Hired to work one Day to assist in pulling down a bridge and to erect another: the bridge fell with him and others on it; and a large quantity of Heavy Timber fell on him: by which he was exceedingly bruised: and also Broke his arm: shoulder: collar bone and Ribs: by which means it Required our Emediate assistance to take Care of Him in his Destressed Condition which your Petitioners have done: and by Extraordinary Care and Expence he is Considerably Recovered and Likely to have the use of his Limbs to a Considerable degree; but is No way able to pay the Cost or ever likely to be able. Nor is there any other Town in America as we know of by Law liable to Reimburse the Cost of his Cure to us: and have no other Remedy but by applying to your Excelency and Honor that the same may be made a province charge.

96. There was, however, one master-servant relation that did have this character and that, nevertheless, did not conform to the rule of self-reliance. Seamen who were injured in the service of their ship or who fell sick during its voyage were held entitled in maritime law to be cured at the ship's expense and to suffer no diminution of wages while incapacitated. Noting in Natterstrom v. The Hazard (1809) 17 Fed. Cas. 1243-50 
that the entitlement was "occasionally questioned by ship owners and masters", the Federal District Court for Massachusetts went to some pains to investigate the matter fully. It concluded, that the ancient maritime codes upon which American maritime law was based - the laws of Oleron, of Wisbuy, and of the Hanse Towns - "wisely and humanely calculated to sooth the sorrows of the sick or disabled mariner" by providing that he be cared for in the event of any calamity, and further that his disablement "should not diminish his stipulated wages, during the existence of his disability, or his necessary absence from the service of the ship from that cause." The court noted that this was exceptional. "The application of the Roman law de locatione et conductione, to which Pothier expressly refers, for a construction of the contract of hiring of labour, in general, and for the hire of seamen, in particular, would exclude a claim for compensation during the disability of the servant or labourer." But just as generous masters would not insist on a strict enforcement of their rights, but would continue to pay the wages of a sick servant notwithstanding his inability to perform his stipulated services, "so the law marine in relation to mariners converts into an obligation what, in other instances of hire, is the result of benevolence." It did so, according to the court, "for the encouragement of seamen, and as a compensation for the risk which they run of an entire loss of wages, from inevitable accidents occurring to the ship, or from a destruction of the voyage."

There were, however, relatively stringent limits to this obligation. First, the patry obliged to meet the expense of maintaining sick or disabled crew members was not the master or owner of the ship but the ship itself (see Dane, Abridgement, 9:202). To the extent that the ship and its cargo also represented the total available assets from which wages could be paid (see The Saratoga. -Keating, claimant. Circuit Court of the United States-Massachusetts [October 1814], reported in American Law Journal, 6 [1815]: 12-20), the expense of maintaining sick crew members was an operating expense shared by all rather than one borne exclusively by the owner. The analogy to the parish or town's obligation to maintain sick or injured servants is imperfect, but it would be incorrect to claim that in the case of seamen the obligation to maintain was exclusively a charge on their masters. Second, the obligation extended only to sickness or disabilities "not produced by [the seaman's] own criminality or fault.". (In Nathan Dane's version of this exclusion, the ship was not responsible for injuries caused by the "vicious or unjustifiable conduct" of a seaman. Abridgement, 2:480). In such circumstances, the seaman "is not entitled to his wages during the time he does no duty; and subsistence, during the same time, may be charged to him." Finally, in the event of the death of a seaman in the service of the ship, no obligation was incurred to pay any form of compensation beyond what was owed to him in wages at the time of his death. Among all categories of hired labor, therefore, seamen alone appear as an exception to the common-law rule of self-reliance alleviated by an entitlement to relief by the community when rendered incapable; and even seamen were at best a qualified exception, one grounded in considerations of "policy""

97. Robert Joseph Pothier, Treatise on the Contact of Letting and Hiring (Contract de Louage), trans. G. A. Mulligan (Durban, 1953), 66.

98. Morton Horwitz has suggested that prior to the era of employer liability litigation most sick or injured workers were probably relieved by their employers from motives of benevolence or charity. Transformation of American Law, 208.

99. Suffolk County Court of Common Pleas, July term 1803; Supreme Judicial Court, November term 1806 (on appeal), Continuing Action 280; November term 1807 (on review) New Entry 307. See also Ratchford v. Niles, Supreme Judicial Court, November term 1807, Continuing Action 58. 
100. "Sickness of Domestics," The Boston Medical and Surgical Journal 2, No. 23 (21 July 1829), 353-54. 39.

101. Massachusetts General Hospital, Annual Report to the Board of Trustees 1836-

102. Some evidence of corporate benevolence earlier than this can be found in Loammi Baldwin's Middlesex Canal Corporation records that show two of the workers reported injured during construction of the canal had payments voted to them by the corporation's board of directors. In the case of Simeon Farmer, the Board voted that Baldwin pay for his board "one month or more in consideration of his suffering occasioned in the work of the canal." Later correspondence reveals that Farmer was off work for fourteen weeks and confronted by bills for medical attendance and board totalling over fifty dollars. Again in September 1800, the Committee on Operations voted $\$ 35$ toward the expenses of Richard Briggs "who had his leg broke blowing stones." That this was by no means the rule, however, is indicated by the case of Martin Nolan, the laborer injured during construction of the Suffolk County Court House. Despite strong support from the architect in charge, Nolan went uncompensated. See above, notes $52-53$ and accompanying text.

103. Ware, Early New England Cotton Manufacture, 61; Wallace, Rockdale, 296-397.

104. Phillip Scranton, Proprietary Capitalism: The Textile Manufacture at Philadelphia, 1800-1885 (New York, 1983), 30-31.

105. Reports of employee injuries and deaths in the minutes of the board of the directors of the Boston and Worcester Railroad reveal that a tendency in the late 1830 s to offer employees or their families fairly substantial cash payments in the event of the injury or death of the employee while in the railroad's service had virtually disappeared by the mid-1840s. See, for example, Directors' Minutes, 3 (meeting of 9 October 1838), detailing payment of $\$ 500$ to the widow of Hiram Bridges, engineer, killed in a collision, and compare with Directors' Minutes 5 (meeting of 11 February 1845), instructing the superintendent to provide relief to John Smith, machinist, severely injured in a machine shop accident, "not exceeding thirty dollars"; and Directors' Minutes 6 (meeting of 20 April 1847), instructing that a subcommittee created to inquire into the circumstances of an accident to John Mitchell, brakeman, in which Mitchell lost his leg, be empowered to pay Mitchell's hospital expenses and also the cost of a wooden leg "if they judge [the latter] expedient."

106. As the owner and operator of the gravel cars, the corporation was to be held to the responsibilities of a common carrier of passengers. It was therefore bound to exercise diligence such as would ensure safe carriage to those riding legitimately, save only from extraordinary accidents. The law would infer from the circumstance of breaking down without apparent cause a prima facie proof of defect or negligence for which the defendant was liable. Thus the burden was on the defendant to show that there was no defect. But this it could not do, for cracked wheels were in use on the cars and had caused the accident. The defendant had admitted by its own action in removing cracked wheels from the passenger train that it did not consider them safe"except," Choate added sarcastically, "for Irish labourers"- and it had failed to show any sort of usage of cracked wheels on other roads that might justify it in seeking to place the risk of riding on a gravel train on the shoulders of the plaintiff.

107. "Suppose the contract general to carry plaintiff and his materials-which is the only reasonable supposition-it is manifest that plaintiff must in such case adopt the usual mode, or some [other] one pointed out by defendants." (Emphasis in original.) If, knowing the rule, he either accidentally by loss of time or for preference chose to 
exercise the privilege of free transportation extended to him by the corporation by taking another mode of conveyance, it was at his own risk.

108. Emphasis in original.

109. Emphasis in original.

110. Emphasis in original.

111. Emphasis supplied.

112. To illustrate his point, Loring offered a homely analogy:

Suppose a private individual not acting as owner of a line of coaches or baggage wagons undertakes to remove a family and its furniture from one place to another. $\mathrm{He}$ is held to no greater care prudence and skill in his vehicle horses and driver than men ordinarily receive. And if this carriage break or be overturned and loss of property or life ensue - he is not accountable unless owing to want of ordinary care and diligence. Whereas if he were acting as Common Carrier or stage coach proprietor he would be liable in one case at all events, and in the other for any want of utmost care and prudence. (Emphasis in original.)

Moreover, "this case would be the same, if a person were thus carrying materials and men to do work upon his home or farm." In either case "reasonable diligence is all that could be required."

113. Emphasis in original.

114. In her outstanding biography of Rufus Choate, Jean V. Matthews has noted that by the 1840 s "although the Whig industrialists did not entirely abandon their original idea of government as a positive force in the economy, they did increasingly resist attempts by government to regulate as well as aid industry. Their property might be social, both in the benefits it dispensed and the fostering it deserved, but its management they regarded as a purely private matter." Jean V. Matthews, Rufus Choate, The Law and Civic Virtue (Philadelphia, 1980), 74.

115. 34 Virginia (7 Leigh) 383.

116. The possibility that plaintiffs would have available to them this means of introducing jury deliberations into the determination of the cause of occupational death is of particular importance in the American context, given the rapid withering away after the Revolution of any recognition of a capacity in coroners' juries to levy fines or "deodands" on the objects (and thus on the owners of the objects) that had "moved to the death" of a victim. On deodands, see Harry Smith, "From Deodand to Dependency," American Journal of Legal History 2 (1967): 389-403. On the role of coroners' juries in the determination of cause of occupational death in England, see Elizabeth Cawthon, "Thomas Wakley and the Medical Coronership-Occupational Death and the Judicial Process," Medical History 30 (1986): 191-202. According to the Corpus Juris Secundum "the doctrine (of deodand) was so repugnant to the American concept of justice that it was not included as a part of the common law of this country." $C$. $J$. S. 26A, 185. See also Parker-Harris Company v. Tate (1916) 135 Tennessee 510.

117. Farwell v. Boston \& Worcester Railroad, Supreme Judicial Court (Suffolk County) November term 1840, Continuing Action 215.

118. 3 M. \& W. 1. This case was originally heard at the Lincolnshire Assizes in July 1836.

119. 1 McMullen 385. This case was originally heard before a jury at Charleston in 1838.

120. Commentary on the argument of counsel in Farwell's case is based on a reconstruction derived from a combination of three sources: Charles Greely Loring's case notes, in Loring Papers; the entries concerning Farwell's case in the minute book of the Chief Justice of the Supreme Judicial Court, Lemuel Shaw (29:244-49), Social Law 
Library, Boston; and the entries concerning the case in the minute book of Justice William Hubbard (1:184-95), Social Law Library, Boston. Unless otherwise indicated, Loring's case notes are the prime source.

121. Horwitz, Transformation of American Law, 210.

122. 3 M \& W. 5-6.

123. 1 McMullan 398-99.

124. Ibid., 400.

125. Shaw was not impressed with Loring's attempt to avoid the action on the case.

"It is questionable whether this action is founded in tort or contract," he recorded in his minutes. "It falters between both." As we have already seen, Loring's argument in Barnes was contract-based. Shaw's minute book.

126. "We do not go upon the principle that the defendants are liable in this case upon the rule regulating their liability to passengers carried for hire. In that case they are liable for the want of the utmost care and prudence of which human foresight is capable. But the servants in their employment do not come within the reason of that rule ... Nor do we rest our claim upon the same principle which lies at foundation of the liability of principals for the acts of their servants."

127. Chief Justice Shaw's minute book reveals the judge noting to himself at this point, "It may be that the remedy in tort is mistaken, causing him to amend the form of action." Similarly, Justice Hubbard's minute book notes that no contract was alleged in the plaintiff's declaration but trespass on the case was the plea.

128. Emphases in the original.

129. The switchman "contracts alone with the defendants and is directly accountable to them." It was the corporation "from whom he receives his compensation [and] who alone can control or dismiss him."

130. "I have looked through all [the] digests and books. [I] have examined [the] civil codes," stated George Morey. Nowhere was there any hint of a rule remotely similar to that for which the plaintiff was contending.

131. According to Justice Hubbard's minutes, Morey likened the relationship between the engineer and the switchman to that pertaining between different parts of the body. "Could the eye complain of the hand and the hand of the foot?" Defense counsel also used the examples of a blacksmith's shop, a stage play, and farmers making hay as illustrations of their point.

132. Ibid.

133. Ibid. Shaw records counsel's remarks slightly differently. "[Respondeat superior] prevails in the civil or cases at the common law yet there has been no case in either code when the legal principle has been so applied. The cases must have happened, time without number, and no such [action] was brought, till lately, and never sustained. It would be a new era in legal history if maintained."

134. Originally, Morey told the court, respondeat superior had been expressly limited to the protection of travellers on the highway and their property from injury. Succeeding cases had, for sound reasons of public policy, subsequently extended the master's obligation to encompass all third persons. It had, however, never been held to extend to indemnify other servants. In Shaw's minute book.

135. Ibid.

136. Mass. Stat.s (1840) c. 80 :

If the life of any person, being a passenger, shall be lost by reason of the negligence or carelessness of the proprietor or proprietors of any rail-road, steam-boat, stage coach, or of common carrier of passengers, or by the unfitness or gross negligence or carelessness of their servants or agents, in this Commonwealth, such proprietor 
or proprietors, and common carriers, shall be liable to a fine not exceeding five thousand dollars, nor less than five hundred dollars, to be recovered by indictment, to the use of the executor or administrator of the deceased person, for the benefit of his widow and heirs.

137. When it came to his rebuttal Loring hedged his bets but, according to Shaw's minutes, he did so rather unconvincingly. "[We] do not place the case on the ground of [the] liability of [the] master for the negligence of servants, but do not decline it, and if the court think it applicable, it [could] be applied."

138. In Hubbard's minute book.

139. Emphasis in original. Hubbard's minutes show that Fletcher emphasized that Farwell's wages as an engineer were higher than those he had received as a machinist, and that there was also a differential between the wages he had been paid as the engineer of the merchandise train and those he received for driving the passenger train.

140. Shaw's minute book.

141. Emphasis in original.

142. Justice Hubbard noted in his minutes that Loring "thinks servants very degraded in England-and so poor [that they] cannot try their cases."

143. 45 Mass. 49 , at 56.

144. Ibid., 57.

145. Ibid.

146. Comment, "Creation of a Common Law Rule," 590-94.

147. 45 Mass. 49 , at 57.

148. See, generally, Boston and Worcester Railroad, Directors' Minutes, Vols. 2-4 (1837-42).

149. Western Railroad, Directors' Records, 2 (1836-41), and Clerk's Files, Case 1, all in Boston and Albany Collection, Baker Library, Harvard Business School; Salsbury, The State, the Investor and the Railroad, 182-85.

150. Report of the Committee on Rail-roads and Canals (Senate Document 55, 1842), 6-9; Salsbury, The State, the Investor and the Railroad, 189.

151. Ibid.

152. Senate Document 55 (1842), 8.

153. 45 Mass. 49 , at 59.

154. Ibid., 58 .

155. Ibid., 59.

156. That such self- and other-discipline were two sides of the same coin in Shaw's decision is confirmed by his reaction to Loring's attempt to distinguish Farwell's claim on the grounds that he and the switchman were employed in different departments. If employees were to be responsible for policing each other, Loring argued, that responsibility could extend only so far as their emjoyment of the means - notably the requisite knowledge - to do so. Shaw, however, refused to entertain the point. First, he challenged Loring on whether the different departments could in fact be distinguished from each other. "When the object to be a ccomplished is one and the same, when the employers are the same, and the several persons employed derive their authority and their compensation from the same source, it would be extremely difficult to distinguish, what constitutes one department and what a distinct department of duty. It would vary with the circumstances of every case." But in any case, Shaw continued, Loring's distinction assumed a principle of employer responsibility which the court did not accept. "The exemption of the master... from liability for the negligence of a fellow servant, does not depend exclusively upon the consideration, that the servant has better means to provide for his own safety, but upon other grounds." Those other grounds were the 
employee's contractual assumption of the risks of his employment. The master was exempt from liability "because the implied contract of the master does not extend to indemnify the servant against the negligence of any one but himself." 45 Mass. 49 , at 60-61. (Emphasis in original.)

157. Carlyle, "Signs of the Times," 42.

158. 57 Mass. 270, and 60 Mass. 75. These were the first cases to come before the Supreme Judicial Court on the question of an employer's liability for occupational injuries after Farwell's suit.

159. 63 Mass. 112, at 115. The plaintiff in this case was an apprentice in the defendant corporation's machine shop but was injured while acting temporarily as a fireman at no advance in his wages. Although the risk premium had been an important element in Shaw's justification of the assumption of risk doctrine, the court in King studiously ignored the inconsistency.

160. 64 Mass. 228, at 231. The circumstances of Gillshannon's case were, of course, identical to those in the suit brought by Gilham Barnes.

161. 70 Mass. 99.

162. Comment, "The Creation of a Common Law Rule," 579.

163. So far as the potential of respondeat superior is concerned, there is no evidence that the principle had ever been applied or even thought of as a rule of sufficient generality as to encompass the imputation of negligence to the employer in cases of injury occurring within an employment relationship. (Respondeat superior, as we have seen, was not invoked in Barnes, nor was it in Priestley v. Fowler). Indeed, earlynineteenth-century Massachusetts lawyers with an interest in the origins of this "ancient customary principle" might reasonably have been led to the conclusion that respondeat superior specifically excused the master from liability for injuries done by one servant to another. In 1808, the American Law Journal, published in Boston and Philadelphia, carried a translation of those elements of Justinian's Pandects that dealt with the responsibilities of masters of ships and of inn- and stablekeepers. "The master must answer for the acts of all his mariners, whether slaves or freemen" indicted the Journal, translating from the eighteenth book of Ulpian; "and it is very proper he should answer, as he himself appoints them." But "he does not answer further than for damage done on board of his vessel; and he is not to answer for any thing done out of the vessel although by mariners." And crucially, "if the mariners occasion damage to each other, no action lies against the master." American Law Journal 1, no. 4 (1808): 496.

The argument that in industrial accident cases judges had to confront respondeat superior as relevant doctrine to be distinguished - or that in Farwell, as Horwitz would have it, the court was spared the necessity of so doing only because of Loring's ineptitude-grows out of the assumption that these cases were part of a larger trend in legal development in which a judiciary sympathetic toward entrepreneurial capitalism reacted to the increasing incidence of tort claims accompanying the industrialization of the northeastern economy by radically diluting preindustrial principles of strict liability through the introduction of liability-limiting criteria such as the fault principle. As I indicated in the introduction to this paper, however, recent research has suggested that injurious behavior in the preindustrial era was governed not by principles of strict liability but by an assumption of no-liability outside carefully demarcated areas. Seen from this perspective, respondeat superior appears less as the doctrinal expression in master-servant relations of wide-ranging, strict-liability assumptions than as one of a limited number of carefully policed enclaves existing in a predominantly no-liability world. Into this enclave the courts admitted injuries suffered by strangers at the hands of servants if the consequence of acts expressly or implicitly commanded by the master 
and occurring within the usual course of his business, but not injuries judged to be the consequence of a servant's "wilful" acts. (Given that the courts' definition of wilful action could extend to any act the performance of which was not involuntary or uncoerced, the realm of potentially uncompensated injuries was left wide indeed). A master was also held liable where an injury appeared to be the result of negligence or want of skill on the part of a servant, "because it was a neglect and fault in the master to appoint a careless and negligent person to do his business." As Nathan Dane indicted, however, there was no guarantee that the principle would extend liability to masters if they could show that the servant they had appointed had otherwise exhibited a "good and faithful character," for it had never been settled "how far one negligent act, as the one complained of, is conclusive evidence of a negligent character in the servant." See Dane, Abridgement, vol. 2, 495, and generally 315-16, 494-95. Even in third-party relations, therefore, respondeat superior did not render the master automatically liable for any injury resulting from his servant's negligence. Rather, the liability of the master was on account of his own fault in appointing an insufficient servant, and might be avoided by demonstrating due care in the choice of the servant.

164. 57 Mass. 270, at 274.

165. 60 Mass. 75 , at 77.

166. 70 Mass. 99 , at 101. She, of course, remained accountable to the superintendent, or any other agent to whom the employer had delegated supervisory authority, on the basis of her contract with the employer.

167. Ibid., 101.

168. Gordon, "Critical Legal Histories," 1122.

169. As Horwitz puts it, in this contractarian world "the only measure of justice was the parties' own agreement." Transformation of American Law, 209.

170. Albro v. Jacquith. 70 Mass. 99, at 101 . On the invisibility of power within the contract of employment, see Alan Fox, Beyond Contract: Work, Power and Trust Relations (London, 1974), 182-84.

171. By disciplinary power I do not mean simply the power to command obedience. Rather, I mean the "mechanism of power which permits time and labour... to be extracted from bodies," which Michel Foucault identified some years ago as the singular invention of the seventeenth and eighteenth centuries. According to Foucault, disciplinary power is power in detail. It "implies an uninterrupted, constant coercion, supervising the processes of the activity rather than the result." It is administered "according to a codification that partitions as closely as possible time, space, movement." Differing from "service," which was "a constant, total, massive, non-analytical, unlimited relation of domination, established in the form of the individual will of the master," disciplinary power became possible "when an art of the human body was born, which was directed not only at the growth of its skills, nor at the intensification of its subjection, but at the formation of a relation that in the mechanism itself makes it more obedient as it becomes more useful." See Foucault, "Two Lectures," in Power/Knowledge: Selected Interviews and Writings, 1972-77, ed. Colin Gordon (New York, 1980), 104; Discipline and Punish: The Birth of the Prison (New York, 1979), 137-38.

172. See generally Karl Renner, The Institutions of Private Law and their Social Functions, ed. Otto Kahn-Freund (London, 1949).

173. Fox, Beyond Contract, 188-89; Richard Kinsey, "Despotism and Legality," in Capitalism and the Rule of Law: From Deviancy Theory to Marxism, ed. Bob Fine, et al. (London, 1979), 46-64.

174. Foucault, Power/Knowledge, 92-108. See also Cousins and Hussain, Michel Foucault, 225-51. For an example of the state-centered analysis of power that Foucault 
wished to criticize, see Gianfranco Poggi, The Development of the Modern State: A Sociological Introduction (London, 1978), 92-107.

175. Foucault, Power/Knowledge, 105.

176. Ibid., 105-7.

177. Robert W. Gordon, "New Developments in Legal Theory," in The Politics of Law: A Progressive Critique, ed. David Kairys (New York, 1982), 286-92. And see Paul Hirst, On Law and Ideology (London, 1979), 113, 146-50; Jacqueline Tombs, "Law and Slavery in North America: The Development of a Legal Category" (Ph.D. diss., University of Edinburgh, 1982), 54-6. 